\title{
Reducing Systemic Risk: The Role of Money Market Mutual Funds as Substitutes for Federally Insured Bank Deposits
}

\author{
Jonathan Macey ${ }^{\dagger}$
}

$\underline{\text { Table of Contents }}$

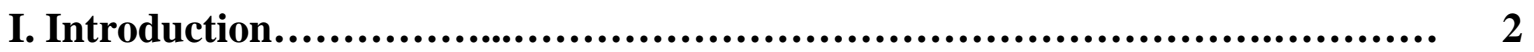

II. A Brief History of the Money Market Mutual Fund Industry.................... 10

III. Money Market Mutual Funds and the Financial Crisis........................ 18

IV. Advantages of Money Market Mutual Funds................................... 29

V. The Current Regulation of Money Market Mutual Funds........................ 45

VI. Proposed Reforms To Money Market Mutual Fund Regulation................ 52

VII. Conclusion...................................................................... 61

\begin{abstract}
In the wake of the events of September 2008, money market mutual funds have made significant changes to the way they invest. Those changes have been driven by business and investment needs as well as by substantial revisions to the regulatory framework in which funds operate. Yet, some policymakers and market participants are calling for additional regulatory or legislative action. This paper lays out the important role that money market mutual funds play in the short-term capital markets, traces the successful regulatory history of money market mutual funds and argues that suggested reforms would create, rather than reduce, systemic risk.
\end{abstract}

\footnotetext{
† Sam Harris Professor of Corporate Law, Corporate Finance, and Securities Law, Yale Law School and Yale School of Management. The author thanks Fidelity Management \& Research Company for data and research support.
} 


\section{Introduction}

In the wake of the 2008-2009 financial crisis regulators and market participants have been focused on the perceived vulnerability of money market mutual funds (MMFs) to systemic risk. The Securities and Exchange Commission has begun to reassess the riskiness of MMFs. ${ }^{2}$ More recently, the Treasury Department directed the President's Working Group (PWG) on Financial Markets to analyze how further to reduce the systemic risk that MMFs may pose to the economy. ${ }^{3}$

The point of this Article is to analyze MMFs and to show that, viewed properly, such funds significantly reduce systemic risk. Certain contemplated changes to the way that MMFs are regulated would increase systemic risk by weakening the role of MMFs in the money markets and increasing market participants’ reliance on commercial banks.

In September 2008, there had been a “run” on certain MMFs when, after the collapse of Lehman Brothers, many investors rushed to redeem their shares. This influx of sellers caused concern that some MMFs would drop below their target price of $\$ 1.00$ per share an extremely rare occurrence known as "breaking the buck" that is highly unsettling to investors. Though September 2008 marked only the second time in history that a MMF fell below $\$ 1.00$ since the product's creation in $1971,{ }^{4}$ the occurrence provoked the SEC to

\footnotetext{
${ }^{2}$ In response to the issues that affected money market mutual funds in late 2008 after Lehman Brothers' bankruptcy filing, the SEC made significant changes to the regulation of such funds. See Money Market Fund Reform, Inv. Co. Act Rel. No. 29,132 (Feb. 23, 2010), available at http:/www.sec.gov/rules/final/2010/ic-29132.pdf. (accessed November 30, 2010); see also Benjamin Haskin, Margery Neale and Ryan Brizek, “SEC Adopts Money Market Fund Reforms,” The Metropolitan Corporate Counsel, April 5, 2010, available at http://www.metrocorpcounsel.com/current.php?artType=view\&artMonth=November\&artYear=2010\&Entr yNo=10803, accessed November 30, 2010.

${ }^{3}$ Report of the President's Working Group on Financial Markets, "Money Market Fund Reform Options,” October, 2010.

${ }^{4}$ The first occurrence was in 1994 when concerns over exposures to interest rate derivatives led investors to withdraw from a particular fund that had taken excessive risk.
} 
enhance its regulations of MMFs. Thus far, the SEC's regulatory changes fall into three main categories: 1) enhanced risk limitations, 2) special provisions for MMFs that break the buck, and 3) more stringent constraints on repurchase agreements. ${ }^{5}$ Additional changes are being considered.

This paper considers the role of MMFs in our financial markets and calls into question the assertion that these funds pose risks to the financial system. It proceeds first by demonstrating the centrality of mutual funds to our financial system and specifically the role of MMFs. Subsequently, the paper explains the operation of these funds in layman's terms and the convenience they present to investors. It then proceeds to consider the role of these funds in the 2008 financial crisis. Having argued that MMFs did not cause or exacerbate the crisis, the paper highlights the advantages that MMFs bring to investors. Finally, it examines the current regulation of MMFs and further proposed changes. Ultimately, the paper argues that over-regulation of MMFs threatens to destroy their value and only to increase the systemic risks to society.

\section{$\underline{\text { An Introduction to Mutual Funds and Money Market Mutual Funds }}$}

Mutual funds are investment vehicles (organized normally as a corporation or a business trust) that use the capital raised from the sale of shares to investors to construct a portfolio of investments. The returns to investors in the mutual fund are a straightforward function of the income and capital gains (or losses) of the mutual fund's investment portfolio. The job of the fund manager is to invest the money received from the sale of these mutual fund shares appropriately in light of the structure of the fund and the investment objectives of the people whose money is being invested. Mutual funds play a

\footnotetext{
${ }^{5}$ As summarized by the PWG. Money Market Fund Reform Options, Report of the President's Working Group on Financial Markets, Oct. 2010 [hereinafter PWG Report].
} 
critical role in our economy. At the end of 2008, the United States had over 16,000 mutual funds with aggregate assets in excess of $\$ 9.6$ trillion. ${ }^{6}$ For further perspective, mutual fund companies held $19 \%$ of the total financial assets of U.S. households, and invested on behalf of $45 \%$ of all U.S. households (92 million individuals, comprising 52.5 million households). ${ }^{7}$ As of October 2010, money market mutual funds had nearly $\$ 3$ trillion of the total amount under management. ${ }^{8}$ Mutual funds are particularly popular in the United States, where roughly one-half of the world's mutual fund industry is located. ${ }^{9}$

The value of a share in a mutual fund is called the "Net Asset Value" of the fund. The Net Asset Value or "NAV" of a mutual fund is the net value of all of its assets (investments) divided by the number of shares outstanding. Thus, the NAV approximates the liquidation value of an investor's shares in a fund. It is the price at which investors can buy fund shares or sell them back to the fund. The fund manager calculates the NAV of the fund each day and, when an investor wants his money back, the fund buys (or “redeems”) the investor's shares at the price per share.

Money market mutual funds - the target of the new SEC regulations - are a genus of "open-end" mutual funds. In an open-end mutual fund, the investors who put their money in such funds gain access to their money by "redeeming” their shares. Redemption is simply a demand by an investor to receive the cash equivalent of the investor's shares.

Money market mutual funds are known as such because they invest in what are known as "money market” instruments. These are securities with very short maturities that tend also to pose only negligible investment risk. MMFs invest in short-term (one day to

\footnotetext{
${ }^{6}$ INV. CO. INST., 2009 INVESTMENT COMPANY FACTBOOK: A REVIEW OF TRENDS AND ACTIVITY IN THE INVESTMENT COMPANY INDUSTRY 19, available at http://www.icifactbook.org/pdf/2009_factbook.pdf. ${ }^{7}$ Id. at 8 \& $72-73$.

${ }^{8}$ PWG Report, at 2.
} 
397 day) debt obligations, such as Treasury bills, federal agency notes, certificates of deposit, commercial paper, and repurchase (or “repo”) agreements. ${ }^{10}$ (See Figure 1). Treasury bills are government promissory notes issued by the U.S. Treasury Department with maturity dates of up to one year; federal agency notes are securities issued to fund the operations of federal agencies, such as Fannie Mae or Freddie Mac (note that these short-term agency debentures are different from long-term agency mortgage-backed securities that consist of underlying residential mortgage loans); bank certificates of deposit (issued by both foreign and domestic banks) are bank-issued debt instruments that pay interest; commercial paper involves short-term obligations issued by banks and corporations; and repo agreements involve the buying of securities on a short-term basis coupled with an obligation by the original seller to repurchase the securities from the buyer at a fixed price at a later date.

\footnotetext{
${ }^{9} \mathrm{Id}$. at 20.

${ }^{10}$ Money market funds may only purchase U.S. dollar denominated assets.
} 


\section{FIGURE 1}

\section{Selected Money Market Instruments March 2010}

\begin{tabular}{|c|c|c|c|}
\hline & \multirow{2}{*}{$\begin{array}{c}\text { Total } \\
\text { Billions of dollars }\end{array}$} & \multicolumn{2}{|c|}{ Money market fund holdings } \\
\hline & & Billions of dollars & Percentage of total \\
\hline Total taxable instruments & $\$ 11,370$ & $\$ 2,361$ & $21 \%$ \\
\hline Agency securities $^{1}$ & 1,167 & 475 & 41 \\
\hline Commercial paper & 1,081 & 457 & 42 \\
\hline Treasury securities $^{2}$ & 2,578 & 382 & 15 \\
\hline Repurchase agreements $^{3}$ & 2,559 & 449 & 18 \\
\hline Certificates of deposit ${ }^{4}$ & 1,997 & 503 & 25 \\
\hline Eurodollar de posits ${ }^{5}$ & 1,989 & 94 & 5 \\
\hline
\end{tabular}

${ }^{1}$ Debt issued by Fannie Mae, Freddie Mac, and the Federal Housing Finance Agency due to mature by the end of March 2011; category exludes agency-backed mortgage pools.

${ }^{2}$ Marketable Treasury securities held by the public due to mature by the end of March 2011

${ }^{3}$ Rep urchase agreements with primary dealers; category includes gross overnight, contin uing, and term agreements on Treasury, agency, mortgagebacked, and corporate securities.

${ }^{4}$ Certficates of deposit are large of jumbo CDs, which are issued in amounts greater than $\$ 100,000$.

${ }^{5}$ Category inclu des claims on foreigners for negotiable CDs and non-negotiable deposits payable in U.S. dollars, as reported by banks in the U.S. for those banks or those banks' customers' accounts.

Sources: Investment Com pany Institute, Federal Reserve Board, U.S. Treasury Department, Fannie Mae, Fred die Mac, Federal Housing Finance Agency, and Federal Reserve Bank of New York

Source: Investment Company Institute

MMFs are designed to serve the needs of investors whose primary goal is the preservation of principal, and who are willing to accept a modest return on their investment portfolio in return for more safety and liquidity. From an economic perspective, MMFs are a substitute for the checking accounts offered by banks and provide consumers a viable alternative to banks. ${ }^{11}$ People who keep their money in MMFs, like those who keep their money in federally insured depository institutions such as commercial banks and credit unions, expect to be able to obtain cash from their funds virtually on demand, and they expect that the value of their investments will not decline in nominal terms.

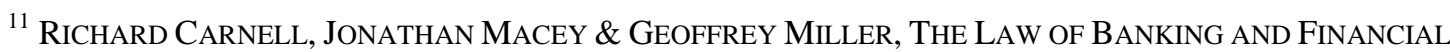
INSTITUTIONS 604 ( $4^{\text {th }}$ ed. 2009).
} 
The moniker "money market" mutual fund distinguishes MMFs from the other sorts of mutual funds, which are designed more for long-term investors rather than for the short-term savers who typically patronize MMFs. The defining feature of a MMF and the characteristic that distinguishes MMFs from other mutual funds is that MMFs generally are able to maintain a stable NAV of $\$ 1.00$ per share by keeping their risk exposures low and by buying short-term debt securities from issuers whose financial strength makes them highly unlikely to default prior to the date on which the securities mature.

For all sorts of mutual funds, including MMFs, the Investment Company Act of $1940^{12}$ nominally requires that each fund calculate its NAV each day on the basis of the current market value of the securities held by the fund. In the case of MMFs, however, the SEC has exercised its authority to carve out exemptions from this general rule. Under this exemptive authority, the SEC has ruled that under certain conditions, MMFs can employ accounting procedures to calculate the value of the securities they own which permit them to offer a stable share value of $\$ 1.00$.

In order to maintain a constant share value, most MMFs use the "amortized cost" method of valuation. Under this method securities are valued at acquisition cost rather than market value, and interest earned on each security (plus any discount received or less any premium paid upon purchase) is accrued uniformly over the remaining maturity of the purchase. By declaring these accruals as a daily dividend to its shareholders, the fund is able to maintain a stable price of $\$ 1$ per share. ${ }^{13}$

Money funds may also use a second procedure called "penny rounding" to maintain a stable share value, although I am not aware of any money funds currently relying on this

\footnotetext{
${ }^{12}$ Pub. L. No. 76-768 (August 22, 1940), codified at 15 U.S.C. § 80a-1-64.

${ }^{13} I d$.
} 
approach. Under this procedure the share value is calculated by rounding the per share market value of the fund to the nearest cent on a share value of a dollar. If the market value of a share is kept within one-half cent of a dollar, this accounting procedure allows the funds to offer a stable $\$ 1$ share value. Thus, if a MMF has a net asset value of $\$ 0.995$, the fund could quote a price of $\$ 1.00$ because the SEC allows the $\$ 0.995$ NAV (which is within one-half cent of a dollar) to be rounded up to $\$ 1.00$.

A large number of factors can cause the NAV of well-managed MMFs to fall below or rise above $\$ 1.00$. For example, a swift upward adjustment in interest rates could reduce the value of portfolio securities below the $\$ 1.00 \mathrm{NAV}$ level. Some classes of assets held by the fund could decline in value. As the average maturity of the securities in a MMF's portfolio increases, so too does the possibility that the NAV will vary somewhat from $\$ 1.00 .{ }^{14}$ Although most attention is paid to NAVs potentially falling below $\$ 1.00$, a fund's NAV could also exceed $\$ 1.00$.

Over time, two major customer constituencies for MMFs have emerged. One group of investors is individual (or "retail") investors who use MMFs instead of, or as a supplement to, their demand deposit accounts and savings accounts. Retail investors also use MMFs to hold cash temporarily or to take a temporary defensive position in anticipation of declining equity markets. As of December 2009, about one fifth of U.S. households' cash balances were held in MMFs. ${ }^{15}$

The second core clientele of MMFs is large institutions, such as bank trust departments, corporations, brokerage accounts, state and local governments, hedge funds,

\footnotetext{
${ }^{14} \mathrm{Id}$.

${ }^{15}$ See INV. CO. INST., 2010 INVESTMENT COMPANY FACTBOOK: A REVIEW OF TRENDS AND ACTIVITY IN THE INVESTMENT COMPANY INDUSTRY 8, available at http://www.ici.org/pdf/2010_factbook.pdf.
} 
and retirement plans. The largest institutional investors in MMFs are corporations ${ }^{16}$ that purchase MMFs directly or indirectly through an intermediary and who use the funds for cash management purposes. A special category of MMFs, generally labeled "institutional-only," has evolved to deal with institutional investors. These funds offer an array of services specially designed to meet the needs of institutions, such as electronic hookups between the institutions and the fund and sub-accounting services to facilitate recordkeeping of banks’ trust accounts. ${ }^{17}$ Many corporate treasurers of large businesses have essentially “outsourced” cash management operations to money market mutual funds.

As of January 2008, approximately 80 percent of U.S. companies used money market funds to manage at least a portion of their cash balances. ${ }^{18}$ U.S. non-financial businesses held approximately 32 percent of their cash balances in money market mutual funds. The prominence of institutional investors in MMFs is a relatively recent phenomenon. From 1998 to 2008, institutional money fund assets grew by 380 percent compared to 63 percent for non-institutional money fund assets. ${ }^{19}$ According to the Investment Company Institute ("ICI"), the national association of U.S. investment companies (including money market mutual funds), about 66 percent of money market fund assets are now held in money market funds or share classes intended to be sold to institutional investors. $^{20}$

MMFs typically require a minimum initial investment from clients in the range of \$500 to \$5,000 for retail investors. MMFs geared towards institutions often have much

\footnotetext{
${ }^{16}$ Id. at 181 , tbl. 59.

${ }^{17}$ Cook and Duffield, supra note 12, at 159.

${ }^{18}$ See Inv. Co. Inst., Report of the Money Market Working Group, at 21 (Mar. 21, 2009), available at http://www.ici.org/pdf/ppr_09_mmwg.pdf (hereinafter “ICI Report”). supra note 7, at 28-29, Figure 3.7.

19 See Inv. Co. Inst., Money Market Mutual Fund Assets, June 11, 2009 http://www.ici.org/highlights/mm_06_11_09 (last visited April 24, 2010).
} 
higher minimum initial investment requirements. MMFs historically required customers to maintain fairly large balances, but that requirement has been relaxed over the past twenty years. Retail MMFs typically permit their investors to write checks against their accounts, or to transfer funds electronically, though there may be restrictions on how many times per month such withdrawals can be made.

While MMFs are the safest category of mutual funds, they historically have not been insured by the federal government. Because of the low risk associated with money market assets, such insurance never has been considered necessary. Moreover, because MMF investors, like other mutual fund investors, are equity claimants and are entitled only to the NAV or their pro rata share of the value of the MMF's assets, it is not possible for a mutual fund to fail in the way that a bank, whose depositors own fixed contractual claims for specific nominal sums, can fail. If a mutual fund's assets decline in value, its investors face a similar decline in the value of their investments. A bank depositor, however, is entitled to the same amount of money from the bank irrespective of any fluctuations in the value of the bank’s investments.

It is possible, of course, for money market funds to suffer a decline in the NAV of the fund's shares, which means that the NAV can fall to a price below $\$ 1.00$ per share. But, because of the effective regulations governing MMFs, this risk has been, and remains, minimal. Historically, even including consideration of the recent crisis, MMFs have been extremely safe.

\section{A Brief History of the Money Market Mutual Fund Industry}

${ }^{20} I d$. 
MMFs date back to 1971 when the Reserve Primary Fund was launched. MMFs experienced their initial period of rapid growth in 1974 and early 1975, as a result of Regulation Q's strict ceiling on the interest rates that insured depository institutions were permitted to pay to depositors. ${ }^{21}$ In the high interest rate environment that existed during this period, money market rates of return rose well above the ceiling on interest that could be paid on deposits accounts. In order to outpace interest and achieve returns higher than those fixed by Regulation Q, many customers withdrew their assets from deposit accounts and placed their funds into money market mutual funds. ${ }^{22}$

The level of MMF assets rose to almost $\$ 4$ billion by mid-1975 and remained in the range of $\$ 3$ billion to $\$ 4$ billion until the end of $1977 .^{23}$ Explosive growth in MMFs occurred again in the late 1970s and early 1980s, when very high money market rates produced large differences in the rates of return being paid by MMFs and depository institutions. Also beginning in the late 1970s, a few of the largest firms introduced the “cash management account” (CMA), a type of MMF that includes check-writing features. CMA accounts provided customers with both market-sensitive yields and the transactional

\footnotetext{
${ }^{21}$ The Banking Act of 1933, Ch. 89, 48 STAT. 162, commonly known as the Glass-Steagall Act, enacted three major reforms that defined banking regulation for the next several decades: (1) the separation of banking from the securities industry; (2) the establishment of federal deposit insurance; and (3) federal controls over deposit insurance, including the prohibition of interest-bearing demand deposits. The third reform, proposed as the Glass provision and enacted as Regulation Q, set limits on the interest rates that banks could pay their depositors. For a treatment of the legislative history of Regulation Q, see R. Alton Gilbert, Requiem for Regulation Q: What It Did and Why It Passed Away, Feb. 1986 Fed. RES. BANK OF ST. LouIs ReV. 22 (1986), available at: http://research.stlouisfed.org/publications/86/02/Requiem_Feb1986.pdf; Michael D. Schley, Interest on Demand Deposits: The Erosion of Regulation Q's Last Stronghold, 4 ANN. REV. BANKING L. 23, 29 (1985).

${ }^{22}$ See, e.g., Arthur E. Wilmarth, Jr., The Expansion of State Bank Powers, The Federal Response, and The Case For Preserving the Dual Banking System, 58 FORDHAM L. REV. 1133, 1143-44 (1990) (describing the impact of the Fed's monetary policy on disintermediation); Laurie S. Goodman and Sherrill Shaffer, The Economics of Deposit Insurance: A Critical Evaluation of Proposed Reforms, 2 YALE J. ON REG. 145, 152 (1984) (arguing that "whenever market interest rates rise about Regulation Q ceilings, bank deposits fall sharply.”).

${ }^{23}$ Cook and Duffield, supra note 12, at 157. See also Brian Reid, Inv. Co. Inst., Perspective: Growth and Development of Mutual Funds 3, available at http://www.ici.org/pdf/per03-02.pdf (analyzing the growth of money market mutual funds from 1970 to 2000).
} 
advantages of a checking account, and as a result MMF assets rose rapidly from $\$ 4$ billion in 1977 to $\$ 235$ billion in $1982 .^{24}$

In order to help banks compete with MMFs, in 1980 Congress passed the Depository Institutions Deregulation and Monetary Control Act (the "DIDMCA”), which created a committee charged with phasing out Regulation Q's limitations on interest and dividends paid to depositors by 1986. Two years later, Congress passed the Garn-St. Germain Depository Institutions Act, which directed this committee to provide depository institutions with an account that would be "directly equivalent to and competitive with money market mutual funds. ${ }^{25}$ These accounts, known as money market deposit accounts (MMDAs), had no limits on the interest depositors could earn. Both the instructions of the DIDMCA and the moniker chosen for these accounts indicate that they were designed in order to allow depository institutions to better compete with MMFs. ${ }^{26}$

MMDAs were extremely successful at first, drawing \$298 million within the first four months of their existence. ${ }^{27}$ The introduction of these accounts caused a predictably sharp drop in MMF balances; from November 1982 to the end of 1983, MMF assets fell by $\$ 67$ billion. $^{28}$ But over time the interest paid on MMDA accounts declined, and by 1986

\footnotetext{
${ }^{24}$ Arthur E. Wilmarth, Jr., The Transformation of the U.S. Financial Services Industry, 1975-2000: Competition, Consolidation, and Increased Risks, 2002 U. Ill. L. Rev. 215, n. 95 (2002); Cook and Duffield, supra note 12 at 157; Franklin R. Edwards \& Frederic S. Mishkin, The Decline of Traditional Banking: Implications for Financial Stability and Regulatory Policy, FED. RES. BANK OF N.Y., ECON POL’y ReV. (July 1995), at 31.

${ }^{25} 12$ U.S.C. § 3503(c)(1)(1982).

${ }^{26}$ See Timothy A. Canova, The Transformation of U.S. Banking and Finance: From Regulated Competition To Free-Market Receivership, 60 BROOK. L. REV. 1295, 1319-20 (1995) (discussing MMDAs in the broader context of the abolishment of virtually all restrictions on the price of credit during the Reagan administration).

${ }^{27}$ See Hans H. Angermueller, Vice Chairman, Citicorp-Citibank, Speech at The Thrift Industry at the Crossroads Conference: The Third Industry: A Breath of Fresh Air (Mar. 25, 1983), in 3 ANN. REV. BANKING L. 155, 160 (1984).

${ }^{28}$ Cook and Duffield, supra note 12.
} 
MMF assets had returned to their 1982 levels. ${ }^{29}$ Since that time, MMF assets have continued to grow, not only as a result of their competitive rates of return, but also because investing in the stock market in general and the mutual fund industry in particular experienced significant growth. This has led to rapid growth because

[I]nvestors often use MMFs as a parking place for cash reserves awaiting investment in longer-term financial assets such as stocks and bonds. They also frequently exchange MMF shares for the shares of other funds in their mutual funds group. Further, MMFs are generally the core vehicle in the popular cash management accounts offered by large brokerage firms. ${ }^{30}$

Another important historical feature of MMFs has been the support that such funds have received from their mutual fund sponsors. Where there has been a risk of decline in the value of a particular class of mutual fund assets, some MMF's advisors have averted the specter of breaking the buck by purchasing securities from the MMFs in an effort to bring the funds' NAVs back to $\$ 1.00$. This has been a considerable source of strength for MMFs and a significant source of comfort to MMF investors, despite the fact that advisors strive to make clear that there are no guarantees to support their funds.

For example, in 1989, when a major commercial paper issuer defaulted on $\$ 213$ million of outstanding paper, two MMFs held enough of the issuer's paper to jeopardize their ability to maintain a $\$ 1.00 \mathrm{NAV}$. The funds' advisors averted the possibility of a decline in the $\$ 1.00$ share value by purchasing the commercial paper from the funds. A year later, two additional issuers defaulted on their commercial paper, and in this case as well, the advisors of MMFs holding these funds came to the rescue by purchasing the

\footnotetext{
${ }^{29} \mathrm{Id}$.

${ }^{30} I d$. at 159.
} 
troubled commercial paper from the funds at a price sufficient to maintain the fund's NAV. ${ }^{31}$ Despite the lack of any losses to investors, as a result of these problems in the commercial paper market, the SEC strengthened even further the restrictions on MMFs.

In 1991, the SEC amended Rule 2a-7 of the Investment Company Act of 1940 to require MMFs that wanted to continue to use the amortized cost or penny-rounding accounting methods to comply with new maturity, credit quality and diversification rules. Specifically, the SEC ruled that the MMF had to invest 95 percent of its assets in

"First Tier" securities, which generally speaking was defined to include Treasury securities or privately issued securities rated A1-P1, and had to invest the remainder in "Second Tier" securities, which are those rated A2-P2. The SEC also required that a fund invest no more than 1 percent of its assets in any particular Second Tier company or 5 percent of its assets in any First Tier company. Finally, the SEC lowered the average maturity requirement from 120 to 90 days. $^{32}$

At this time, the SEC promulgated its rule making it illegal for a registered mutual fund to describe itself as a "money market" fund unless it met the stringent requirements of Rule 2a-7. This provision effectively defined a money market fund as a mutual fund that follows the risk-limiting provisions of Rule 2a-7. And, significantly, since 1991 the SEC has required that a money market fund prospectus prominently disclose that the MMF's shares are neither insured nor guaranteed by the U.S. government and that there is no assurance that the funds will be able to maintain a stable value of $\$ 1$ per share. The express

\footnotetext{
${ }^{31} I d$.

${ }^{32}$ Id.; see also, Leland Crabbe and Mitchell Post, The Effect of SEC Amendments to Rule 2a-7 on the Commercial Paper Market, Finance and Economics Discussion Series \# 199, Washington: Board of Governors of the Federal Reserve System (May 1992) (demonstrating the reduction in MMFs' holdings of A2-rated paper following the imposition of this regulation and conclude that the regulation raised the interest rate on $\mathrm{A} 2$ paper relative to the rate on $\mathrm{A} 1$ paper).
} 
purpose of this rule is to increase investor awareness that investing in a money market fund is not without risk.

The new regulation did not deter securities firms from establishing money market mutual funds. In 1992, MMFs represented $\$ 544$ billion in deposits, while other mutual funds such as bond and equity funds managed over $\$ 1$ trillion in investor funds. ${ }^{33}$

In 1994, many money market funds experienced portfolio losses, but their investors were again shielded from any loss when managers made up for these losses themselves. ${ }^{34}$ In one case, however, fund managers found themselves unable to redeem investor shares. Community Bankers Mutual Fund, Inc., a small MMF catering to small community banks had made ill-timed investments in adjustable rate securities, which lost value as interest rates climbed in 1993-94. The Fund had $\$ 35.5$ million of its $\$ 82.2$ million in assets in derivatives when it was forced to liquidate its assets to redeem shares. ${ }^{35}$ This was the first time in the 23-year history of MMFs that a fund broke the buck, and no further failures would occur until 14 years later, at the height of the financial crisis in 2008.

Arthur Levitt, Jr., then Chairman of the SEC, warned investors that there is no guarantee that MMFs will maintain a stable $\$ 1.00 \mathrm{NAV}$. "The moral is that any fund can lose money," said Levitt. "This serves as a warning of the steps the S.E.C. needs to take to protect investors who are not aware of the risk they are undertaking.”36

\footnotetext{
${ }^{33}$ David G. Oedel, Puzzling Banking Law: Its Effects and Purposes, 67 U. Colo. L. REv. 477, 498 (1996).

${ }^{34}$ In 1994, BankAmerica and 13 other banks or brokers paid $\$ 60$ million to cover derivative losses in two money market funds. The Paine Webber Group put up \$268 million to cover customer losses, and Piper Jaffray Companies put up \$25 million in a fund that lost \$700 million from derivatives. See Leslie Wayne, Investors Lose Money in "Safe" Fund, N.Y. Times, Sept. 28, 1994, at D1; Chart, "Pumping Money Into Their Funds," id. at D6 (listing fifteen MMFs whose advisors covered for shortfalls in 1994 or 1994, bailing out their funds to avoid "breaking the buck.").

${ }^{35} I d$.

${ }^{36} I d$.
} 
In the last decade or so, the biggest change in money market mutual funds has been the dramatic increase in the number of institutional investors in money market funds. From the end of 1998 to the end of 2008, retail money market mutual funds grew from approximately $\$ 835$ billion to $\$ 1.36$ trillion, or 63 percent, while institutional money market fund assets grew from approximately $\$ 516$ billion to $\$ 2.48$ trillion, a staggering 380 percent. (See infra Figure 2; Figure 3). 


\section{FIGURE 2}

Figure 3.2: Assets of Money Market Funds in Retail and Institutional Share Classes

March 2010 $34 \%$

Retail

share classes

(\$1.0 trillion)

$$
66 \%
$$

Institutional

share classes

(\$2.0 trillion)

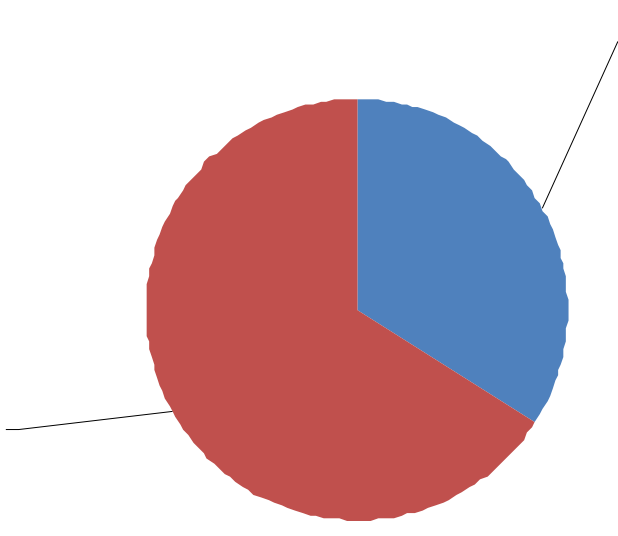

Source: Investment Company Institute

\section{FigURE 3}

Figure 3.3: Selected Characteristics of Retail and Institutional Money Market Fund Share Classes March 2010

Median minimum initial investment Median average account balance* Percentage of funds offering check writing Total number of shareholder accounts

\begin{tabular}{r|r}
\multicolumn{1}{l|}{ Retail } & \multicolumn{1}{|c}{ Institutional } \\
\hline$\$ 1,000$ & $\$ 1$ million \\
$\$ 56,318$ & $\$ 4.4$ million \\
$62 \%$ & $12 \%$ \\
26.4 million & 5.8 million
\end{tabular}

* The median of the average account balance for each type of share class across all money market funds.

Sources: Investment Company Institute and iMoneyNet

Source: Investment Company Institute

Due in large part to the growth of institutional funds, money market mutual funds have increased substantially over the last decade, from approximately $\$ 1.4$ trillion at the 
end of 1998 to approximately $\$ 3.8$ trillion in assets at the end of $2008 .{ }^{37}$ At the onset of the financial crisis, more than 750 money market funds were registered with the Commission, ${ }^{38}$ and money market funds accounted for approximately 39 percent of all investment company assets. ${ }^{39}$

\section{Money Market Mutual Funds and the Financial Crisis}

Unusually poor performance by a handful of MMFs in the wake of the financial crisis has sparked increased criticism of MMFs and a call for significant reforms to the existing regulatory structure. But no action directly taken by any MMF contributed to the credit crisis. And although MMFs did not escape the turbulence entirely unscathed, the overwhelming majority of MMF shareholders did not lose a single-penny in the crisis, and no investors lost more than two cents on the dollar. Of the more than \$3 trillion in MMF assets in 2008, only a very small amount (i.e., the size of the Reserve Primary Fund at the time of its demise) actually resulted in losses to shareholders.

The financial crisis is commonly understood as resulting from an unprecedented period of excessive borrowing and lending, particularly in the market for subprime residential mortgages. The crisis resulted in the collapse of many major financial institutions. Among them was Lehman Brothers Holdings Inc. ("Lehman Brothers”), which declared bankruptcy on September 15, 2008 after accruing massive losses in mortgage backed securities.The panic resulting from the Lehman bankruptcy spread

\footnotetext{
${ }^{37}$ INV. CO. INST., 2009 INVESTMENT COMPANY FACTBOOK, supra note 6, at 146, tbl. 37.

${ }^{38}$ Sec. \& Exch. Comm'n, Money Market Fund Reform, Release No. IC-28807; File No. S7-11-09, available at http://www.sec.gov/rules/proposed/2009/ic-28807.pdf (hereinafter “SEC Proposal”).

${ }^{39}$ Id.
} 
throughout the market, and soon other, normally stable institutions, including some money

market mutual funds, came under pressure. On September 16, 2008, a MMF broke the buck for the first time in fourteen years when the share price of the Reserve Primary Fund fell below the presumptive NAV minimum of $\$ 1.00$ per share. ${ }^{40}$ Over the course of the crisis, fund sponsors (other than Reserve Primary) made up for losses within portfolios, just as they had in the past. ${ }^{41}$

Reserve Primary, the nation's oldest MMF, had been rated 'AAAm' by Standard \& Poor's (which immediately lowered its principal stability fund rating to 'Dm') when the Fund broke the buck). ${ }^{42}$ The fund's assets had risen 95 percent during 2008 to $\$ 125$ billion, as investors ditched falling equity markets for safer investments. To any observer in 2007 or early 2008, Reserve Primary looked like a safe investment fund.

\footnotetext{
${ }^{40}$ Christopher Condon, Reserve Primary Money Fund Falls Below \$1 a Share, Bloomberg.com, Sept. 16, 2008, http://www.bloomberg.com/apps/news?pid=20601087\&sid=aAj1pHOSthQA\&refer=home (last visited April 24, 2010).

${ }^{41}$ While mutual funds are not required to report all such transactions (See 17 C.F.R. 270.17a-9), in the 12 month period prior to the collapse of the Reserve Fund, more than a dozen money fund sponsors provided funding to their MMF affiliates to prevent them from breaking the buck - among these were a $\$ 600$ million bailout of the Columbia Money Funds by its sponsor, the Bank of America. Columbia Funds were the seventh largest manager of money market mutual funds with over $\$ 150$ billion in assets. Legg Mason, SEI Investments Co. and SunTrust Banks Inc. also contributed funds to prevent their MMF's NAV from falling below \$1. Bloomberg, "Bank of America, Legg Mason Prop Up Their Money Funds", November 13 2007, available at http://www.bloomberg.com/apps/news?pid=newsarchive\&sid=aWWjLp8m3J1I\&refer=home; SEC Proposal 32691 at nn.39 \& 40 (July 8, 2009), available at http://www.sec.gov/rules/proposed/2009/ic-28807fr.pdf; Alistair Barr, "HSBC’s Bailout Puts Pressure on Citi, Superfund,” MarketWatch, Nov. 26, 2007, available at http:// www.marketwatch.com/story/hsbcs-35-bln-sivbailout-puts-pressure-on-citi-superfund; Shannon D. Harrington \& Christopher Condon, Bank of America, Legg Mason Prop Up Their Money Funds, Bloomberg, Nov. 13, 2007, available at http://www.bloomberg.com/apps/ news?pid=20601087\&sid=aWWjLp8m3J1I\& refer=home; Jim Stack, “Money Market Funds: How Safe Are They?” Forbes, October 10, 2008, available athttp://www.forbes.com/2008/10/10/citigroup-morganstanley-aig-pf-guru-in_js_1010advisersoapbox_inl.h tml.

${ }^{42} \mathrm{~S} \& \mathrm{P}$ rates as 'AAAm' those funds providing "extremely strong capacity to maintain principal stability and to limit exposure to principal losses due to credit, market, and/or liquidity risks." S\&P rates as "Dm" those funds that have "failed in [their] capacity to maintain principal stability, resulting in a realized or unrealized loss of principal." Standard \& Poor's, Principal Stability Fund Ratings, http://www2.standardandpoors.com/portal/site/sp/en/eu/page.article/2,1,6,5,12.04845624989.html (last visited April 24, 2010).
} 
In the year leading to its demise, however, Reserve Primary had made an investment decision that tied its fate to Lehman Brothers and essentially assured its destruction. In mid-2007, Reserve Primary began to reduce its holdings of repurchase agreements and bank CDs in favor of commercial paper, which it held little to none of at the time. The proportion of the fund's assets in commercial paper grew from 1 percent in July 2007 to nearly 60 percent just one year later. (See Figure 4). In September 2008 Reserve Primary held \$785 million of what had until then been considered an extremely safe investment: Lehman Brothers-issued commercial paper. In the two days before Lehman's bankruptcy, the fund suffered redemptions of approximately $60 \%$, reducing its assets to $\$ 23$ billion. And on September 16, the day after Lehman declared bankruptcy, the fund's Board decided to value all of the Lehman debt at zero.

\section{FIGURE 4}

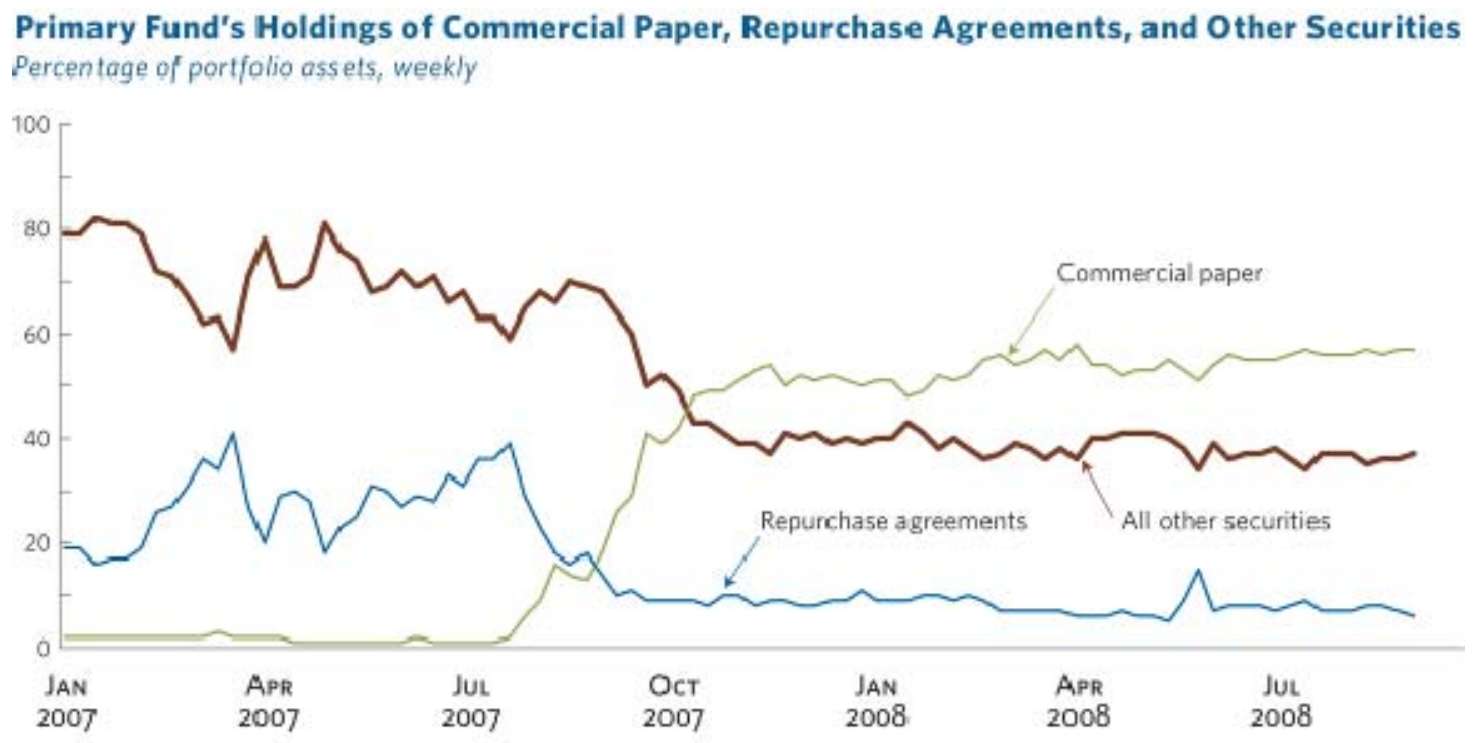

Source: Investment Company Institute 
Although the media instantly mourned Reserve Primary's "failure” and "collapse," the fund did not close for business on September 16, 2008. Rather, the fund set 3:00 p.m. on September $16^{\text {th }}$ as a cutoff time. If a redemption request came in before 3:00 p.m. the redeeming shareholder promptly received the full $\$ 1.00 \mathrm{NAV}$, but any redemption requests after 3:00 p.m. were delayed and received a slightly reduced NAV. And even though one wouldn't get this impression in light of the regulatory response, it must be stressed that Reserve Primary did not entirely leave their investors in the lurch. Rather, when the fund “broke the buck,” Reserve Primary’s NAV fell just three pennies, to $\$ 0.97$ a share. This drop occurred in two stages. First, the NAV went to $\$ 0.99$ when the $1 \%$ Lehman position was priced at zero. Second, shareholder redemptions caused a further dilution of less than two additional cents. Afterwards the fund was liquidated in a process overseen by the SEC. The distributions to date have resulted in shareholders receiving over $\$ 0.99$ per share, so the loss has been less than one penny per share. ${ }^{43}$

While it has been suggested that these events indicate that money market mutual funds are "not robust enough to withstand a major disruption," 44 this is not the case for two reasons.

A. In a Properly Functioning Legal and Market Environment, Commercial Paper is an Investment with a Low Risk of Loss for MMFs

Commercial paper is the trade name for short-term promissory notes that financial and industrial corporations issue to raise capital. ${ }^{45}$ For many years, commercial paper has

\footnotetext{
${ }^{43}$ Press Release, The Reserve Primary Fund to Distribute \$215 Million, (July 15, 2010), www.reservefunds.com/pdfs/Primary\%20Distribution_71510.pdf (last visited August 8, 2010).

${ }^{44}$ See Press Release, U.S. Dep't of the Treasury, T-G-645 (April 20, 2010), available at http://www.treas.gov/press/releases/tg645.htm.
} 
comprised a substantial portion of the short-term corporate debt securities outstanding in the economy. Commercial paper is used by finance companies and industrial companies as a low-cost substitute for bank loans to raise cash to finance current operations; (operating expenses), to provide working capital (i.e., to finance accounts receivable and inventory) and even to finance construction projects. ${ }^{46}$ Commercial paper is, “[f]or most large, highly rated corporations . . . the primary source of short-term credit."47 Commercial paper investors are institutions with excess cash that want high-quality, short-term investments with a fixed, competitive rate of return. Money market mutual funds and commercial bank trust departments invest in commercial paper, as do life insurance companies and pension funds. ${ }^{48}$

Companies that issue commercial paper have lines of credit from banks, which they can access for purposes of supporting outstanding commercial paper, if necessary. Boards of Directors typically restrict the amount of money that corporations can borrow through the issuance of short-term note obligations such as commercial paper to an amount no greater than the maximum amount of funds available under the company's committed credit facilities at any given time. In other words, the maximum amount of commercial paper that companies can issue generally cannot be greater than the amount available under the credit facilities. $^{49}$

\footnotetext{
${ }^{45}$ Jonathan R. Macey, Special Interest Groups Legislation and the Judicial Function: The Dilemma of Glass-Steagall, 33 EmORY L. J. 1, 3-4. See also Evelyn M. Hurley, The Commercial Paper Market, 63 FED. Res. Bull. 525, 525 (1977); Kenneth V. Handal, The Commercial Paper Market and the Securities Acts, 39 U. CHI. L. REV. 362, 363-364 (1972).

${ }^{46}$ See Thomas K. Hahn, Commercial Paper, Fed. Res. Bank of Richmond Virginia Econ. Q., Vol. 79, no. 2 , at 45.

${ }^{47}$ Marc R. Saidenberg \& Philip Strahan, Are Banks Still Important for Financing Large Businesses?, Current Issues in Econ. and Fin., FED. REs. BANK OF NEW YoRK, Vol. 5, no. 12, at 2.

${ }^{48} I d$.

${ }^{49}$ Such restrictions typically appear in corporate resolutions, although sometimes these restrictions are reflected in corporate bylaws.
} 
The point, of course, is that these bank lines of credit are available as a source of strength to back up commercial paper when the companies that have issued such commercial paper experience financial distress. ${ }^{50}$ In a typical example, in the period just prior to its collapse (between October 26, 2001 and November 6, 2001), Enron Corporation drew down its lines of credit and repurchased its outstanding commercial paper of more than $\$ 1.1$ billion. Many of these repurchases were made only days prior to the maturity of the commercial paper. ${ }^{51}$ Thus, it is clear that as long as MMFs invest in commercial paper issued by companies with sufficient bank lines of credit (and as long as legal risk is removed from the use of those lines of credit to repay outstanding commercial paper), then commercial paper is not a source of instability for MMFs, and thus MMFs will be able to withstand major dispruptions.

B. The Problems In MMFs Were Minor, Well-Managed And Were a Manifestation of The Crisis, Not a Cause of the Crisis.

Reserve Primary's breaking the buck did not precipitate the crisis; it was a product of the crisis. ${ }^{52}$ By the time the United States District Court for the Southern District of New York issued an order providing for the liquidation of the fund and the pro rata distribution of its remaining assets on November 25, 2009 (over a year later), shareholders had already

\footnotetext{
${ }^{50}$ On the one hand, the committed lines of credit that banks extend to ${ }_{=}$issuers of commercial paper pose risks to the banks that extend such lines of credit and therefore the structure of the commercial paper market poses risks to the banking system as a whole. However, the commercial paper market provides a significant source of income to the banks that participate in it. Moreover, commercial paper is a direct substitute for bank loans, so that the presence of a vibrant commercial paper market in which banks participate actually reduces risk. See Jonathan Macey, “A Conduct Oriented Approach to the Glass-Steagall Act,” 91 YALE L.J. 102 (1981). ${ }^{51}$ In re Enron Creditors Recovery Corp. v. J.P. Morgan Sec., Inc., 407 B.R. 17, 21 (Bankr. S.D.N.Y.2009). A claim that using back-up lines of credit to repurchase outstanding commercial paper can be set aside in bankruptcy because such payments are preferential transfers, would be highly inadvisable. See In re Enron Creditors Recovery Corp.. 422 B.R. 423 (S.D.N.Y. 2009)

${ }^{52}$ See Edmund L. Andrews \& Michael M. Grynbaum, Fed Weighs Bid to Spur Economy as Markets Plummet Worldwide, N.Y. TIMES, Oct. 7, 2008, at A1; Joe Nocera, 36 Hours of Alarm and Action as Crisis Spiraled, N.Y. TIMES, Oct. 2, 2008, at A1 (describing problems that could arise if MMFs abandoned commercial paper); Franklin R. EdWARDS, The NeW FinAnCE: Regulation \& FinANCiAl Stability (1996).
} 
received 92 percent of the assets they had held as of the close of business on September 15, 2008. ${ }^{53}$ With the January 2010 distribution of assets, shareholders have received over 99 cents on the dollar. ${ }^{54}$ Many other financial institutions also suffered substantial losses resulting from Lehman's collapse. One cannot overstate the level of concern in the money markets during this timeframe that other similarly important institutions might fail. The fear and near panic among investors and banks in late 2008 has been well documented. ${ }^{55}$ In light of significant doubts as to the long-term prospects of banks and financial instutions around the globe, investors of all types sought to limit exposure to counterparties, and fled to the safety of cash or Treasury securities. As a consequence, some short-term markets seized up, impairing access to credit by participants in the short-term private debt market. By the end of September 2008, as part of the general contraction in the money markets, money market funds had reduced their holdings of top-rated commercial paper by $\$ 200$ billion, or 29 percent. $^{56}$

It is also true that other MMFs ran into problems during the crisis. Money market mutual fund Evergreen Investments experienced losses and was bailed out by its parent, Wachovia. ${ }^{57}$ Putnam Investments, like Reserve Primary one of the oldest names in the mutual fund industry, liquidated its Putnam Prime Money Market Fund, a \$12.3 billion fund. Although Putnam Prime had no exposure to Lehman, the fund had 35\% of its assets

\footnotetext{
${ }^{53}$ Press Release, The Reserve,Court Issues Order Regarding Securities and Exchange Commission's Proposed Plan for Distribution of Reserve Primary Fund's Assets (Nov. 27, 2009), http://www.reservefund.com/fundsnews.shtml (last visited April 24, 2010).

${ }^{54}$ Reserve, Reserve Primary \$215 Million, supra note 43.

${ }^{55}$ FinANCIAL CRISIS INQUiRy COMMISSION, PRELIMINARY STAFF REPORT: SHADOW BANKING AND the FINANCIAL CRISIS 31-40, (May 4, 2010), available at http://fcic.gov/reports/pdfs/2010-0505-Shadow-Banking.pdf (last visited May 12, 2010).

${ }^{56}$ See Christopher Condon \& Bryan Keogh, Funds' Flight from Commercial Paper Forced Fed Move, BLOOMBERG, Oct. 7, 2008, available at http://www.bloomberg.com/apps/news?pid=newsarchive\&sid=a5hvnKFCC_pQ.
} 
in commercial paper, which is a very low-risk asset in general but which it was required to sell on short notice at "fire sale" prices in order to meet unexpected redemptions from its concentrated institutional investor base and prevent losses for remaining investors. ${ }^{58}$

American Beacon Advisor, Inc.'s Money Market Select Fund also experienced substantial redemption requests, which it quickly satisfied by providing that all proceeds exceeding $\$ 250,000$ in a 90 -day period would be paid by making pro-rata payments of cash and in-kind distributions of securities held by the fund. ${ }^{59}$ Neither Evergreen, nor Putnam Prime, nor Select Fund broke the buck.

Some general purpose money market mutual funds, especially institutional funds, experienced substantial investor flight to treasury bills and other Treasury and government MMFs. Over the course of the week, there was a net outflow from money market funds of $\$ 170$ billion. As the pace of withdrawals increased, regulators worried about the stability of the MMF industry and the functioning of the commercial paper market. In order to preserve the assets of the country's principal purchasers of short-term debt, particularly commercial paper, the government acted decisively. On September 19, 2008, the Federal Reserve Board announced its plan to expand its emergency lending program to help commercial banks finance the purchase of asset-backed securities from money market mutual funds. ${ }^{60}$

\footnotetext{
${ }^{57}$ Christopher Condon, Bloomberg News, Reserve Primary Money Fund Falls Below \$1 a Share, Sept. 16, 2008, http://www.bloomberg.com/apps/news?pid=newsarchive\&sid=a5O2y1go1GRU.

${ }^{58}$ Diana B. Henriques, Treasury to Guarantee Money Market Funds, N.Y.TiMES.COM, Sept. 20, 2008, http://www.nytimes.com/2008/09/20/business/20moneys.html (last visited April 24, 2010).

${ }^{59}$ See American Beacon Funds, Prospectus Supplement for BBH ComSet Class, Institutional Class, Cash Management Class, and Plan Ahead Class (Sept. 30, 2008), available at http://www.sec.gov/Archives/edgar/data/809593/000080959308000045/sep3008_prosuppbeacon.txt.

${ }^{60}$ Press Release, Bd. of Governors of the Fed. Reserve Sys., Bd. Announces final rules pertaining to the Asset-Backed Commercial Paper Money Market Fund Liquidity Facility, Regulations H, W, and Y, (Jan. 30, 2009), http://www.federalreserve.gov/monetarypolicy/20090130a.htm (last visited April 24, 2010).
} 
On the same day, the Treasury Department announced that it would guarantee all money market funds against losses with $\$ 50$ billion from the Exchange Stabilization Fund. 61 "For the next year, the U.S. Treasury will insure the holdings of any publicly offered eligible money market mutual fund - both retail and institutional - that pays a fee to participate in the program,” the Treasury Department said in a statement. The Treasury Department explained its goal to “enhance market confidence and alleviate investors' concerns about the ability for money market mutual funds to absorb a loss.”62

Modeled after FDIC insurance for bank deposits, the Temporary Guarantee Program for Money Market Funds (the “Guarantee Program”) was designed to be triggered if a participating fund's net asset value fell below $\$ 0.995$. The Treasury Department based its power to insure the money market on the Gold Reserve Act of 1934, the statute that had created the Exchange Stabilization Fund (ESF). ${ }^{63}$ This guarantee was unusual in that its coverage was tied specifically to balances on one day: September 19, 2008.

Most money market funds took advantage of this program, including some of the nation's largest such as Charles Schwab, Federated, Fidelity, Morgan Stanley, Putnam Investments, BlackRock and JPMorgan Chase. These entities had all enrolled by October 1, 2008, by which time investors had continued to pull cash out of prime funds and money market fund assets had decreased to $\$ 3.33$ trillion. ${ }^{64}$

\footnotetext{
${ }^{61}$ Press Release, U.S. Dep’t of the Treasury, “Treasury Announces Guaranty Program for Money Market Funds” (Sept. 19, 2008), http://www.treasury.gov/press/releases/hp1147.htm (last visited April 24, 2010). ${ }^{62} I d$.

${ }^{63}$ See Steven M. Davidoff and David Zaring, Regulation by Deal: The Government's Response to the Financial Crisis, 61 Admin. L. Rev. 508 (2009) (characterizing the ESF-backed insurance program as "[a]d hoc, marked by a rapid response to unprecedented financial market chaos, and authorized by an unconventional interpretation of a Depression-era statute that created a program meant to do something else”).

${ }^{64}$ Diana B. Henriques, As Cash Leaves Money Funds, Financial Firms Sign Up for U.S. Protection, N.Y. Times, Oct. 2, 2008, at C10.
} 
The program quickly drew criticism from several organizations, including the Independent Community Bankers of America and American Bankers Association, who expected funds to drain out of bank deposits and into newly insured money funds. In any event, Congress acted to ensure that the program would not be attempted again. The final version of the EESA provided that the Secretary of Treasury was "prohibited from using the Exchange Stabilization Fund for the establishment of any future guaranty programs for the United States money market mutual fund industry.”65

As an additional measure, the Federal Reserve Bank of New York ("FRBNY”) set up the Commercial Paper Funding Facility to provide assistance to the commercial paper market by creating a special purpose vehicle that purchases commercial paper directly from eligible issuers. The FRBNY also created the Money Market Investor Funding Facility (the "MMIFF"), which provided a credit facility to qualifying private sector special purpose vehicles to enable them to purchase commercial paper and other money market instruments from MMFs, although I am not aware of any funds using the MMIFF.

Money market funds or their advisers paid an estimated \$813 million in premiums under the Treasury's Guarantee Program, but not a single claim was made under the program. ${ }^{66}$ By the end of February 2009, the assets of money market funds had achieved an all-time high of just less than $\$ 3.9$ trillion. (See Figure 5). These government actions, along with other efforts to shore up the financial system in the face of the crisis, undoubtedly served to renew confidence in money market mutual funds and to stimulate new

\footnotetext{
${ }^{65}$ Emergency Economic Stabilization Act of 2008, Pub. L. No. 110-343, § 131, 122 Stat. 3797 (2008), (codified at 12 U.S.C. § 52336).

${ }^{66}$ See Shefali Anand, Treasury Pads Coffers in Bailout, WALL ST. J. (February 17, 2009), available at http://www.online.wsj.com/article/SB123483112001495707.html.
} 
investment in MMFs, although federal intervention was probably not necessary to "rescue" shareholders of “failed” MMFs.

\section{FIGURE 5}

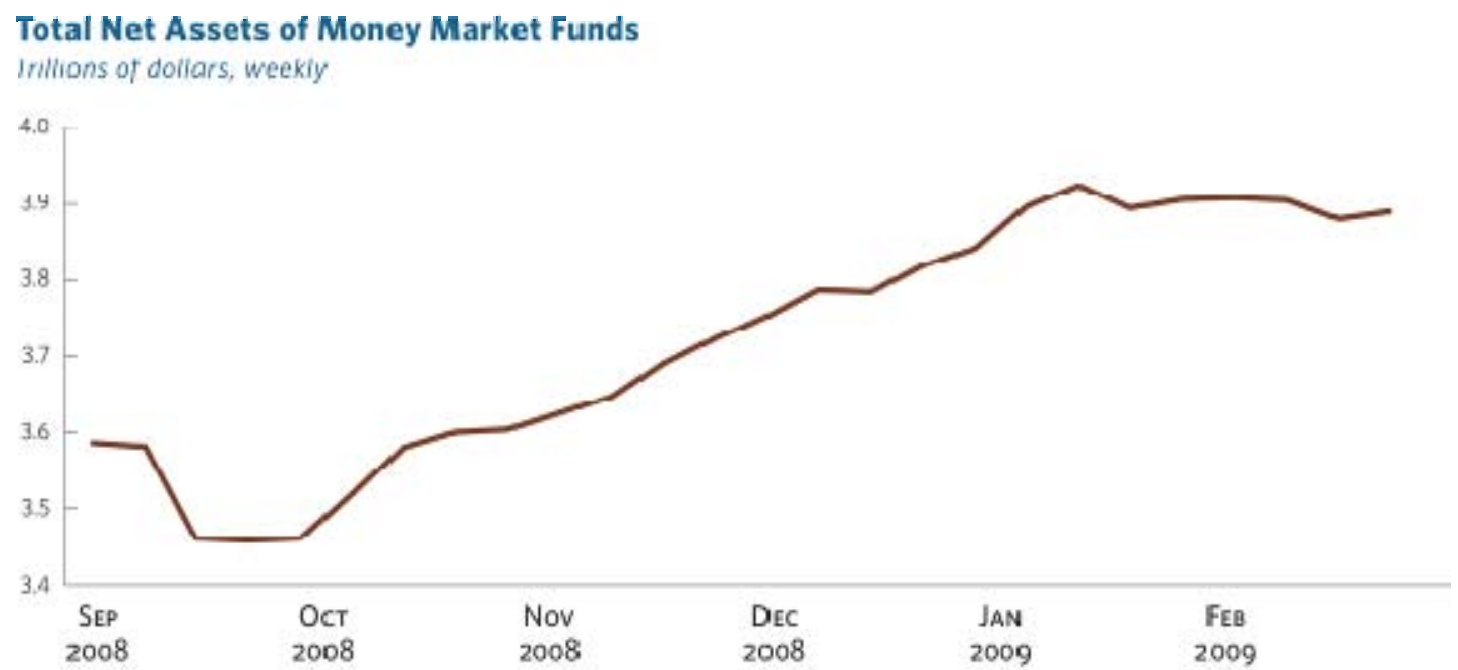

Source: Investment Company Institute

These temporary, emergency measures were designed to complement a comprehensive regulatory scheme for MMFs that has existed since 1983. Although functionally similar to banks' money market deposit accounts, MMFs have distinct characteristics that have always required a unique regulatory scheme tailored to their strengths. 


\section{Advantages of Money Market Mutual Funds}

\section{A. MMFs Diversify Risk By Reducing Pressure On The FDIC}

The structure of commercial banking is inherently fragile and susceptible to disruption in the form of bank runs. ${ }^{67}$ This is because commercial banks have very little capital compared to other sorts of companies, and because there is a structural mismatch between the long-term maturities of their assets and the short-term maturities of their deposit base. Banks' liabilities are largely in the form of deposits that are available to their depositors on demand, while their assets are primarily in the form of loans with longer maturities. Moreover, while the deposits are maintained at a constant and immediately available value, banks' assets are not only highly illiquid, but also highly opaque and difficult to value.

As a result, banks do not have sufficient funds on hand to satisfy all depositors at once. If a substantial portion of a bank's depositors wanted to withdraw their funds at one time, the bank would be forced to liquidate assets at distressed prices. Such liquidation would render the bank insolvent and jeopardize the interests of those depositors who were not attempting to maintain immediate repayment — potentially resulting in a complete loss of amounts deposited. As such, runs on banks can cause economic instability, requiring substantial regulation and monitoring.

In order to prevent bank runs, the Federal Deposit Insurance Corporation (FDIC), a government corporation and independent agency created by the Glass-Steagall Act, provides deposit insurance guaranteeing the safety of deposits in member banks of up to $\$ 250,000$ per depositor. The FDIC is unique among federal agencies in that it receives no 
Congressional appropriations, but is funded exclusively by premiums that banks and thrift institutions pay for deposit insurance coverage and from earnings on investments in Treasury securities. The FDIC does have a line of credit with Treasury, which Congress has temporarily increased in part due to the recent stresses placed on the FDIC's resources. Deposit insurance is held in the Deposit Insurance Fund (DIF), which was created with the merger of the Bank Insurance Fund (BIF) and Savings Association Insurance Fund (SAIF) in 2005.

According to the FDIC, “[s]ince the start of FDIC insurance on January 1, 1934, no depositor has lost a single cent of insured funds as a result of failure." ${ }^{\prime 68}$ In fact, Congress has repeatedly increased the coverage level for deposit insurance from its original figure of $\$ 2,500$ to its present level of $\$ 250,000$. The most recent increase in the coverage level from $\$ 100,000$ to $\$ 250,000$ in 2008 was made permanent by Section 335 of the recently enacted Dodd-Frank Wall Street Reform and Consumer Protection Act. Even adjusted for inflation, the level of coverage has increased significantly over the years, representing approximately six times the value in real terms over the coverage level set in $1934 .{ }^{69}$ These increases in coverage represent de facto reductions in deposit insurance premiums, because the government agreed to take on significantly greater risk without increasing the premiums. ${ }^{70}$ The DIF's finite resources are therefore increasingly at risk of depletion.

The collapse of the Federal Savings and Loan Insurance Corporation (FSLIC) provides a stark warning that government insurance funds can be depleted. FSLIC, an

\footnotetext{
${ }^{67}$ For a more detailed treatment of the mismatch in term structure of commercial banks' assets and liabilities, see Jonathan R. Macey and Geoffrey P. Miller, Deposit Insurance, The Implicit Regulatory Contract, and the Mismatch in Term Structure of Banks' Assets and Liabilities, 12 YALE J. ON REg. 1, 1-4 (1995).

${ }^{68}$ FDIC, "Who is the FDIC?," available at http://www.fdic.gov/about/learn/symbol/index.html

${ }^{69}$ U.S. Bureau of Labor Statistics, Consumer Price Index (CPI) Inflation Calculator, available at http://data.bls.gov/cgi-bin/cpicalc.pl.
} 
institution administered by the Federal Home Loan Bank Board (FHLBB), was created as a part of the National Housing Act of 1934 in order to insure deposits in savings and loans, commonly known as thrifts. During the savings and loan crisis of the 1980's, the FSLIC became insolvent.

The savings and loan crisis of the 1980's and 1990's has, at least until 2008 long been considered the greatest collapse of U.S. financial institutions since the Great Depression. In the late 1980's, the U.S. savings and loan (S\&L), or thrift industry, which had been created in the late $19^{\text {th }}$ century to support local saving and lending, essentially failed. ${ }^{71}$ From 1986 to 1995 , the number of federally insured savings and loans in the United States declined from 3,234 to 1,645, primarily as a result of unsound real estate lending practices. ${ }^{72}$ The failure of these thrifts, which held total assets of over $\$ 500$ billion, completely overwhelmed the resources of the FSLIC. The corporation was recapitalized with $\$ 15$ billion of taxpayer money in 1986 and $\$ 10.75$ billion in 1987. By 1989, FSLIC was considered too insolvent to save and was abolished along with the FHLBB. Upon the dissolution of the FSLIC, the corporation's task of insuring savings and loan institutions was transferred to the FDIC. At final reckoning, the thrift crisis had cost American taxpayers approximately $\$ 124$ billion and the thrift industry another $\$ 29$ billion, for an estimated total loss of approximately $\$ 154$ billion. $^{73}$

\footnotetext{
${ }^{70}$ Jonathan Macey \& Geoffrey Miller, Nondeposit Deposits and the Future of Bank Regulation, 91 Mich. L. REV. 237, 239-241 (1992).

${ }^{71}$ See The SAVINGS AND LOAN CRisis: Lessons From A Regulatory FAILURE (James R. Barth, Susanne Trimbath \& Glen Yago eds., 2004).

${ }^{72}$ Timothy Curry and Lynn Shibut, The Cost of the Savings and Loan Crisis: Truth and Consequences, Dec. 2000 FDIC BANKING REV. 26 (2000), available at http://www.fdic.gov/bank/analytical/banking/2000dec/brv13n2_2.pdf.

${ }^{73}$ FDIC, 13 BANKING REVIEW 33 (2000), available at http://www.fdic.gov/bank/analytical/banking/2000dec/br2000v13n2.pdf.
} 
The less pressure that is placed on the FDIC's resources, the better. FSLIC collapsed, and so did the state-run deposit insurance funds of Maryland and Ohio. The pressure on the FDIC generally increases during times of crisis, and the last few years have been no exception. Despite some commentators' belief that the financial crisis is winding down, banks across the country continue to collapse at an alarming rate. Approximately 150 FDIC-insured depository institutions failed in 2010 alone. $^{74}$

MMFs serve a vital economic purpose of relieving pressure on the FDIC insurance fund. The best way to counter the inherent systemic risk posed by the banking system is to provide investors with a viable alternative to investing in checking accounts in banks. For several decades, MMFs have provided an attractive alternative to checking accounts. The co-existence of money market mutual funds and bank checking accounts is a good diversification strategy for the economy and reduces systemic risk, since some people’s core savings will invariably be tied up in savings accounts and others will invest primarily in money market mutual funds.

In addition, MMFs do not suffer from the same structural mismatch between their assets and liabilities that banks face. Because of the maturity and liquidity requirements imposed on MMFs by Rule 2a-7 of the Investment Company Act of 1940, the investments made by MMFs are more closely aligned with the obligations that MMFs face when shareholders redeem. Recent amendments to Rule 2a-7 strengthen these requirements even further by increasing liquidity requirements and shortening further the maturity limitations for MMF investments.

Apart from their role in relieving pressure on the FDIC, MMFs generally provide value by compensating for shortcomings in bank regulation. Government guarantees of

\footnotetext{
${ }^{74}$ FDIC, Failed Bank List, available at http://www.fdic.gov/bank/individual/failed/banklist.html. 
bank liabilities are less helpful to depositors than they appear, since some, if not all, of the benefits of credit enhancement are eroded by the lower interest rates banks must pay for deposits. In fact, the primary beneficiaries of the regulatory system are the banks themselves, since government guarantees of their liabilities enhances their credit and lowers their costs of doing business. ${ }^{75}$

Despite their dubious benefits, such guarantees rarely, if ever, meet with concerted political opposition. This is because the diffuse depositors who must bear the costs of these programs generally view themselves as beneficiaries of the schemes, which are marketed by bureaucrats, politicians and interest groups as consumer protection devices. Similarly, once a bank has collapsed, the political pressure for a government bailout can become very great, since the depositors have incentives to form an effective political coalition demanding repayment on the grounds that government supervision created a reasonable expectation of government protection from risk of loss. ${ }^{76}$

Considering the political popularity of government-sponsored deposit insurance, it appears unlikely that Congress will scale back or repeal deposit insurance. Congress has never reduced the insurance ceiling per depositor, even after the savings and loan disaster of the 1980s. ${ }^{77}$ Accepting the phasing out of deposit insurance as politically infeasible, regulators should promote alternatives to savings accounts to maximize yield for investors as well as to reduce pressure on the finite assets of the FDIC. By competing directly with banks for deposits, MMFs hedge the social costs of deposit insurance as well as decrease the likelihood that widespread failure in the banking system would deplete the FDIC's

\footnotetext{
${ }^{75}$ Curry and Shibut, supra note 72 , at 19-20.

${ }^{76} \mathrm{Id}$.

${ }^{77}$ Phillips F. Bartholomew, Cong. Budget OfF., Removing Federal Deposit Insurance 34-37 (Sheila Harty ed., 1990).
} 
funds and require another government bailout of the federal banking insurance industry.

Moreover, investors have indicated that changing money market funds to a floating NAV will result in movement of significant assets to banks. This potentially massive flow of money to banks will only increase the pressure on the FDIC, resulting in greater systemic risk.

In our 1992 treatment of money market mutual funds and other "nondeposit deposits," Geoffrey Miller and I noted that MMFs, as a viable substitute to savings accounts, provide an important benefit by challenging the dominance of depository institutions:

Perhaps the most important consequence of the growth of nondeposits for the long-range prospects and stability of the banking system is that they promise to convert federal deposit insurance from an essentially mandatory form of social insurance, which persons wishing to consume economic transactions are forced to accept without any real choice as to whether the benefits of the insurance are worth the costs, into an optional system that consumers can utilize if they wish or can avoid if they are willing to incur the risks of conducting their affairs through higher yielding, but un-insured, transaction accounts...If deposit insurance can be made essentially a voluntary program, the costs of such insurance can then be better imposed on those wishing to obtain its benefits. In such a world, deposit insurance will survive if its benefits exceed its costs; but if the costs of deposit insurance - in terms of the moral hazard and subsidization of risk-taking that it creates, and the elaborate regulatory restraints that must be instituted to correct for these problems - turn out to exceed the benefits, then deposit insurance will wither away to a largely vestigial - and therefore socially unproblematic - program. $^{78}$

B. MMFs Can Reduce Systemic Risk So Long As They Are Subject To Their Own Regulatory Scheme

\footnotetext{
${ }^{78}$ Macey and Miller, Nondepost Deposits, supra note 70, at 272.
} 
Money market mutual funds have fundamentally different assets from commercial banks, and therefore provide an important method for regulators and policy-makers to diversify the risks associated with the banking system. In this way, money market mutual funds are a critical mechanism for reducing systemic risk in the American financial system.

Although there are many varying definitions of systemic risk, a common factor is that a trigger event causes a chain of bad economic consequences, typically a chain of financial institution and market failures. This is why legislation purporting to regulate systemic risk tends to follow hard on the heels of financial crises and market disasters, most notably with the passage of the Banking Act of 1933 (the Glass-Steagall Act), the Securities Act of 1933, and the Securities Exchange Act of 1934 at the height of the Great Depression and the recent passage of the Dodd-Frank Act. ${ }^{79}$ Steven Schwarcz has adopted the following definition of systemic risk: "the risk that (i) an economic shock such as market or institutional failure triggers (through a panic or otherwise) either (X) the failure of a chain of markets or institutions or $(\mathrm{Y})$ a chain of significant losses to financial institutions, (ii) resulting in increases in the cost of capital or decreases in its availability, often evidenced by substantial financial-market price volatility." ${ }^{80}$ Similarly, the International Monetary Fund defines systemic risk as "a risk of disruption to financial services that is (i) caused by an impairment of all or parts of the financial system and (ii) has the potential to have serious negative consequences for the real economy," ${ }^{81}$ for

\footnotetext{
${ }^{79}$ Jonathan R. Macey, Some Observations in the Context of Systemic Risk, in BROOKINGS-WHARTON PAPERS ON FinANCIAL SERVICES 405 (Robert E. Litan and Anthony M. Santomero, eds. 1998).

${ }^{80}$ Steven L. Schwarcz, Systemic Risk, 97 GEO. L. J. 193, 204 (2008).

${ }^{81}$ Staff of the International Monetary Fund and the Bank for International Settlements, and the Secretariat of the Financial Stability Board, Guidance to Assess the Systemic Importance of Financial Institutions, Markets and Instruments: Initial Considerations; Report to the G-20 Finance Ministers and Central Bank Governors, Oct. 2009, at 2.
} 
example, by causing a reduction in productive investment by reducing credit provision or destabilizing economic activity. ${ }^{82}$

Too much homogeneity among risk-management strategies of financial institutions can increase systemic risk. ${ }^{83}$ In each of the three major crises of the last decade, we have witnessed the dangerous effects of homogenous risk management practices, where “competition among the major investment banks can periodically produce a mad momentum that sometimes leads to a lemmings-like race over the cliff. This in essence happened in the period just prior to the 2000 dot-com bubble, again during the accounting scandals of 2001-2002, and most recently during the subprime mortgage debacle." ${ }^{\text {,4 }}$ Some scholars have posited that excessive regulation may perversely create this homogeneity. ${ }^{85}$

Advocates of more stringent, prudential regulation of money market mutual funds often cite these funds' functional similarities to checking accounts in banks. Paul Volcker, former Federal Reserve Chairman and head of President Obama’s Economic Recovery Advisory Board, has said that if MMFs “are going to talk like a bank and squawk like a bank, they ought to be regulated like a bank."86 The Group of Thirty recommended that MMFs offering bank-like services "should be required to reorganize as special-purpose banks, with the appropriate prudential regulation and supervision...”87

\footnotetext{
${ }^{82}$ John Kambhu, Til Schuermann and Kevin J. Stiroh, Hedge Funds, Financial Intermediation, and Systemic Risk, Dec. 2007 Fed. Res. BANK OF NEW York Policy ReV. 5 (2007).

${ }^{83}$ Eric F. Gerding, Code, Crash, and Open Source: The Outsourcing of Financial Regulation To Risk Models and the Global Financial Crisis, 84 WASH. L. REV. 127, 184 (2009).

${ }^{84}$ John C. Coffee \& Hilary A. Sale, Redesigning The SEC: Does The Treasury Have A Better Idea?, 95 VA. L. REV. 707, 745 (2009). See also Wilmarth, The Transformation, supra note 14, at 345, 349 (stating that in light of uncertainty and asymmetric information in the OTC derivatives market, traders "often conclude that the safest strategy is to mimic observed positions taken by other major traders").

${ }^{85}$ See, e.g., Carol Alexander, The Present and Future of Risk Management, 3 J. Fin. ECONOMETRICs 3 (2005); Jonathan Macey, Regulatory McCarthyism, WALL ST. J., Oct. 25, 2006, available at http://online.wsj.com/article/SB116165420539301595.html?mod=opinion_main_commentaries.

${ }^{86}$ Shefali Anand, Money-Fund Bailout Has Been Winner, WALL ST. J., Feb. 17, 2009, at C1.

${ }^{87}$ The Group of Thirty, Financial Reform: A Framework for Financial Stability 9 (2009), available at http://www.group30.org/pubs/recommendations/pdf.
} 
Imposing identical regulatory schemes on entities with significant differences in institutional structure would be a mistake. Banks and money market mutual funds have major structural differences requiring varied regulatory approaches. For instance, MMF managers have different incentive structures, and therefore different agency costs from traditional bank managers, whose salaries are largely fixed. Furthermore, MMF investors receive returns based on the total performance of the fund, whereas a depositor's returns are largely fixed and irrespective of portfolio composition. ${ }^{88}$

One of the principal arguments justifying bank supervision is the depositor-shareholder agency conflict. Under this theory, depositors are generally unsophisticated and have much less access to information than shareholders. Therefore, depositors are generally powerless to control shareholder behavior. Although present in banks, this conflict is not an issue for money market mutual funds. SEC regulations ensure that investors in money market mutual funds do not suffer from this asymmetric information problem. Whereas depositors in a bank cannot easily gain information about the bank's liabilities, money market funds, under the recent Rule 2a-7 amendments, will be required to make full holdings publicly available on a monthly basis.

As Charles Whitehead noticed in a recent article detailing these differences, these characteristics make direct limits on MMFs' investments the best tools in reducing the portfolio risks to which their investors are subject. In fact, and as I will discuss in Part V, MMFs are subject to unique limitations on what types of assets they can hold. Regulators seeking to instead impose banking regulations on MMFs should heed Professor

\footnotetext{
${ }^{88}$ Charles K. Whitehead, Reframing Financial Regulation, 90 B.U. L. REV. 1, 41-42 (2010).
} 
Whitehead's warning that "focusing only on function is unlikely to lead to optimal regulation., ${ }^{89}$

Another principal difference between a bank deposit and a MMF involves the differences in credit risk that an investor assumes. Through deposits, customers are exposed to one entity that is able to lend or invest as it sees fit with no disclosure requirements. When investing in a MMF, the investor is buying a diversified basket of securities, which exposes the investor to the securities of a number of different entities, the identities of which are all disclosed to investors on a monthly basis. This diversification decreases the investor's credit risk particularly when compared with the bank deposit. This argument applies with particular force to institutional customers with large amounts to invest, who may benefit only partially from FDIC insurance at banks that is capped at $\$ 250,000$.

C. MMFs Provide Businesses With Liquidity By Investing in Commercial Paper and

Repos

In a speech at the Council on Foreign Relations on March 10, 2009, Federal Reserve Chairman Ben Bernanke noted that money market mutual fund regulation reform is particularly important in light of "the crucial role they play in the commercial paper market." ${ }^{90}$ Indeed, money market mutual funds provide a significant benefit to the economy by investing in commercial paper. MMFs are by far the largest holders of

\footnotetext{
${ }^{89} \mathrm{Id}$.

${ }^{90}$ Ben S. Bernanke, Financial Reform To Address Systemic Risk, 6 NO. 4. Sec. Litig. ReP. 18, (2009) (partial transcript of speech delivered at a meeting of the Council on Foreign Relations in Washington, D.C., on Mar. 10, 2009).
} 
commercial paper, owning almost 40 percent of all outstanding commercial paper. ${ }^{91}$ (See Figure 6).

\section{FIGURE 6}

\section{Figure 2.4}

Taxable Money Market Funds' Holdings of

Commercial Paper

60

Percentage of total commercial paper outstanding, quarterly

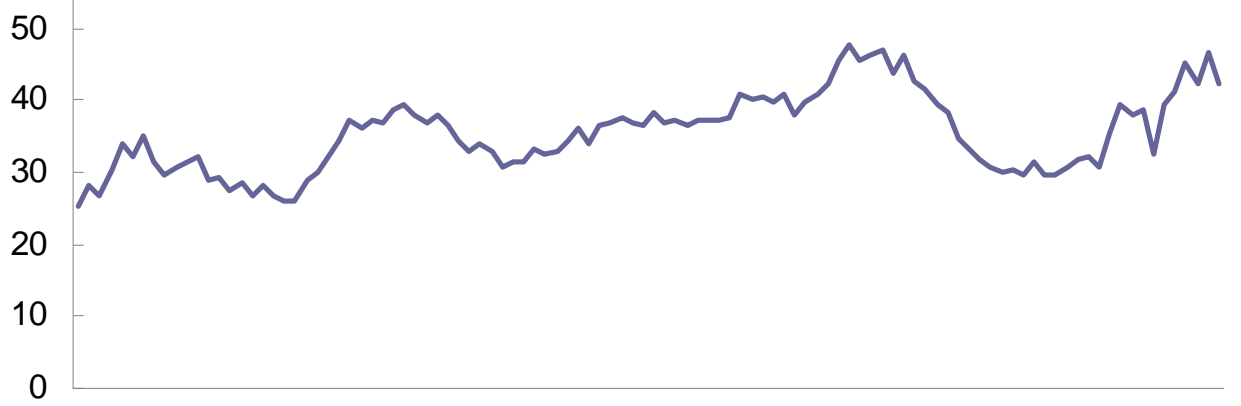

19831985198719891991199319951997199920012003200520072009

* Data for 2010 are through March.

Sources: Investment Company Institute and Federal Reserve Board

Source: Investment Company Institute

Commercial paper is often viewed as a lower-cost alternative to bank loans. In commenting on the SEC’s proposed changes to Rule 2a-7 under the Investment Company Act and in particular on a proposal to prohibit MMFs from investing in securities that receive the second highest credit rating, the U.S. Chamber of Commerce stated that such a prohibition, "could decrease borrowing flexibility and elevate borrowing costs for [issuers of second-tier rated securities], thereby restricting their ability to meet their short-term cash

\footnotetext{
${ }^{91}$ Federal Reserve BoArd, Statistical RElEAse Z.1: FlOW OF Funds ACCOUnTS Of The United STATES: FlOWS AND OUTSTANDINGS FOURTH QUARTER 2008, at 86, Table L.208 (Mar. 12, 2009), available at http://www.federalreserve.gov/releases/z1/Current/z1.pdf (last visited April 24, 2010).
} 
needs, increasing their cost of capital, and driving up consumer costs."92 Once a business becomes established, and builds a high credit rating, it is often cheaper to draw on a commercial paper than on a bank line of credit. Large investors such as MMFs purchase commercial paper because it is relatively safe and often comports with the minimal credit risk determinations made by investment advisers to MMFs under Rule 2a-7. Commercial papers have short maturities, and most issuers have strong balance sheets and good credit ratings. $^{93}$

The amount of commercial paper outstanding grew dramatically in the 1980s, temporarily surpassing the size of the U.S. Treasury bill market in $1988 .^{94}$ This is primarily because the interest rate on bank loans typically exceeded the rate high-quality commercial paper issuers paid in the commercial paper market. ${ }^{95}$ Financial disintermediation created a situation where corporations issued large amounts of commercial paper to investors moving funds away from banks. This growth paralleled the growth in MMFs, which soon became the primary purchaser of commercial paper. In the late 1980s, MMFs had as much as $50 \%$ of their assets invested in commercial paper.

The increase in commercial paper was further aided by technological innovations. Computers and communication technology permitted transactions at very low costs, and complicated modeling permitted financial institutions such as MMFs to more accurately evaluate borrowers. The commercial paper market is now the primary source of short-term funding for investment-grade corporations.

\footnotetext{
${ }^{92}$ The U.S. Chamber of Commerce and Joint Treasurer Signatories, Preserving the Ability of Money Market Funds to Invest in A2/P2 Securities (September 24, 2009), at 2, available at $<$ http://www.sec.gov/comments/s7-11-09/s71109-150.pdf > .

${ }^{93}$ Leland Crabbe \& Mitchell A. Post, The Effect of SEC Amendments To Rule 2A-7 on the Commercial Paper Market 1 (May 1992) (hereinafter "Crabbe \& Post”).

${ }^{94}$ Mitchell A. Post, The Evolution of the U.S. Commercial Paper Market Since 1980, FED. RES. BuLl. 880 (December 1992).
} 
Defaults on high quality commercial paper are extremely rare, which explains why the collapse of Lehman Brothers, which issued massive amounts of commercial paper, had dramatic consequences for the commercial paper market. Before Lehman's collapse, only eight issuers had defaulted on commercial paper: three in 1989 (notably Integrated Resources), four in 1990 (notably Mortgage and Real Estate Trust), and one in 1991. In 1991, as a result of pressure on MMFs after $\$ 883$ million in commercial paper defaults, the SEC amended Rule 2a-7 to add a requirement that a money market fund invest no more than five percent of its assets in second-tier commercial paper and at most one percent of its assets in the paper of any particular second-tier issuer.

In his influential article on credit rating agencies, Frank Partnoy critiqued the 1991 amendments for encouraging credit rating agencies to sell a "regulatory license" to commercial paper issuers. ${ }^{96}$ After 1991, since issuers needed "first-tier" ratings in order to sell commercial paper to MMFs, credit rating agencies had a regulatory license to "sell" high ratings to such issuers. Partnoy cited Crabbe and Post's findings that after the Rule 2a-7 amendments forced funds to reduce their investments in medium-grade commercial paper, the size of the medium-grade commercial paper market declined and the yield spread between medium-grade and high-grade commercial paper increased by more than fifty percent. ${ }^{97}$ Partnoy suggests that the SEC action was an unwarranted overreaction, since all eight issuers that defaulted in 1989-1991 had high credit ratings and were considered "first-tier" issuers. ${ }^{98}$

\footnotetext{
${ }^{95}$ Crabbe \& Post, supra note 93, at 4.

${ }^{96}$ Frank Partnoy, The Siskel and Ebert of Financial Markets?: Two Thumbs Down For The Credit Rating Agencies, 77 WASH. U. L.Q. 619, 699-700 (1999).

${ }^{97}$ Id. at 699.

${ }^{98}$ Crabbe \& Post, supra note 93, at 7 n. 8.
} 
The commercial paper market was extremely stable from 1991 to 2008. As discussed in Part III, the collapse of Lehman Brothers in September 2008 led to government intervention in the commercial paper market in the form of a Federal Reserve Board program to lend to issuers that were unable to tap investors for cash directly. ${ }^{99}$ As of March 18, 2010, the market stands at $\$ 1.22$ trillion in size on a seasonally adjusted basis, having fallen substantially from a peak of $\$ 2.2$ trillion in July $2007 .{ }^{100}$ Financial markets depend on the availability of a market for commercial paper, and if the market suffers further, it will become more costly and difficult for companies to obtain short-term financing.

Money market mutual funds play a similarly vital role in the market for repurchase agreements, which compose a significant portion of the holdings of MMFs. ${ }^{101}$ Repurchase agreements (or repos) are contracts for the sale and future repurchase of a financial asset. On the repurchase date, the seller repurchases the asset at the same price at which he sold it, and pays interest for the use of the funds. Although legally a sequential pair of sales, in effect a repo is a short-term interest-bearing secured loan. The securities that the mutual fund purchases are considered to be collateral for the loan. The securities most frequently used in connection with repurchase agreements are Treasury securities and other U.S. Government securities.

While the participants in the repo market are large, sophisticated institutional investors, the market is a very important part of the general economy. When testifying

\footnotetext{
${ }^{99}$ Anusha Shrivasteva, Commercial Paper Down in Week Ended March 17, Dow Jones Newswires, Mar. 18, 2010, http://online.wsj.com/article/BT-CO-20100318-708794.html?mod=WSJ_latestheadlines (last visited April 24, 2010).

${ }^{100} \mathrm{Id}$.

${ }^{101}$ For the five year period 2005-2009, Repurchase Agreements comprised $10.4 \%$ of the total net assets of taxable, non-government money market funds.
} 
before the Financial Services Committee of the U.S. House of Representatives, Treasury Secretary Timothy Geithner described overnight repos as being "of critical importance to the economy because it is the funding basis for the traditional banking system. Without it, traditional banks will not lend and credit, which is essential for job creation, will not be created [sic]."102

The repurchase market provides MMFs and other institutions with an attractive opportunity to invest their cash balances on a day-to-day basis. Such investments direct short-term funds to their area of greatest need at a low cost, thereby improving the overall efficiency of the financial markets and the economy. Because most repo transactions have a one-day maturity, they are extremely liquid and, as such, enable MMFs and other insitutions to deploy cash overnight on a secured basis while enabling the other party to the transaction to obtain overnight financing. ${ }^{103}$ Timely performance of the seller's obligation to repurchase is critical to these institutions, which require the funds to meet other financial obligations. "For such entities as state and local governments, public and private pension funds, money market and other mutual funds, banks, thrift institutions, and large corporations, repos have become a vital tool of cash management." ${ }^{\text {104 }}$

Mutual funds, particularly money market mutual funds, invest in repos on a short-term basis to assist in managing their portfolios. MMFs also invest in repos in order to maintain a degree of liquidity in their portfolios, which is particularly important to the orderly operation of MMFs using the amortized cost or penny rounding methods of

INV. CO. INST., 2010 INVESTMENT COMPANY FACTBOOK: A REVIEW OF TRENDS AND ACTIVITY IN THE INVESTMENT COMPANY INDUSTRY 166, TBL. 43, available at http://www.ici.org/pdf/2010_factbook.pdf.

${ }^{102}$ Gary Gorton, Questions and Answers about the Financial Crisis: Prepared for the U.S. Financial Crisis Inquiry Commission, Feb. 20, 2010, http://online.wsj.com/public/resources/documents/crisisqa0210.pdf (last visited April 24, 2010).

${ }^{103}$ FInANCIAL CRISIS INQUIRY COMMISSION, supra note 55, at 20.

${ }^{104}$ Omnibus Bankruptcy Improvement Act of 1983, S. Rep. No. 65, $98^{\text {th }}$ Cong., $1^{\text {st }}$ Sess. (1983). 
portfolio valuation. High return with relative safety and the ability to specify term are the key elements of repos which make them attractive to money market mutual funds. MMFs are required to be highly liquid and are used by millions of investors on a daily basis for investment in and redemption of fund shares. The ability to redeem promptly, at net asset value, is crucial to the operation of these funds and the maintenance of investor confidence.

Like commercial paper, repos also are important in the broader financial markets. Repos are the principal method by which primary U.S. government securities dealers finance their portfolios. ${ }^{105}$ According to the Federal Reserve Bank of New York, on April 14, 2010 the outstanding amount of repos entered into by the primary dealers for the U.S. government, federal agency, government sponsored enterprise, mortgage-backed and corporate securities was over $\$ 2.5$ trillion, of which more than $\$ 1.7$ trillion were overnight transactions. The statistic for reverse repos was just under $\$ 2$ trillion. For both repos and reverse repos, the lion’s share were U.S. treasury securities. ${ }^{106}$

The repo market also plays an important role in the conduct of monetary policy. Repos and reverse repos have long been a principal method by which the Federal Reserve regulates the supply of funds. ${ }^{107}$ The Federal Open Market Committee, through the Trading Desk at the Federal Reserve Bank of New York, makes extensive use of repos in regulating the supply of funds in the execution of monetary policy. ${ }^{108}$

\footnotetext{
${ }^{105}$ Joint Report on the Government Securities Market, Dept. of the Treasury, Sec. and Exch. Comm'n, and Bd. of Governors of the Fed. Reserve Sys. (Jan. 1992) at A-11.

${ }^{106}$ Fed. Res. Bank of N.Y., Financing By Primary U.S. Government Securities Dealers, www.ny.frb.org/markets/statistics/deal.pdf; see also NY Fed study shows need for 'repo' backstop facility, Reuters, April 22, 2010, http://www.reuters.com/article/idUSN2212425820100422?type=marketsNews (last visited April 24, 2010).

${ }^{107}$ S. Rep. No. 65, $98^{\text {th }}$ Cong., $1^{\text {st }}$ Sess. 46 (1983).

${ }^{108}$ The Federal Reserve Bank of New York has also announced its intention to engage in repurchase agreement transactions with MMFs. Federal Reserve Bank of New York, Statement Regarding Reserve Repurchase Agreements, August 3, 2010, http://www.newyorkfed.org/markets/opolicy/operating_policy_100803.html (last visitied August 8, 2010)
} 
The efficient functioning of the repo market also facilitates substantial involvement by foreign central banks, monetary authorities, and international institutions in financing the U.S. public debt. The New York Fed maintains accounts for approximately 140 foreign central banks, monetary authorities, and international institutions. With such large institutional holdings of the dollar, it has become important to the orderly financing of the public debt that these institutions purchase U.S. government securities. Therefore, the existence of an efficient repo market in government securities enhances the attractiveness of the U.S. dollar as an international reserve currency.

\section{$\underline{\text { V. The Current Regulation of Money Market Mutual Funds }}$}

Critics of money market mutual funds claim that such funds are part of a "shadow banking system" that operates with "no supervision." This is hardly true. In fact, one former SEC chairman has said that "[n]o issuer of securities is subject to more detailed regulation than mutual funds." ${ }^{109}$ MMFs are subject to a strict regulatory scheme centered around SEC Rule 2a-7, which was promulgated by the SEC under the Investment Company Act and was substantively amended in 1991 and in 2010 to impose greater limits on the types of assets that MMFs can hold.

The success of the money market mutual fund industry speaks to the credit of these regulations. Since the SEC adopted a special regulatory regime for MMFs in 1983, the total net assets of MMFs have increased eightfold, from approximately \$500 million to

\footnotetext{
${ }^{109}$ Money Market Mutual Funds: Hearings Before the Subcomm. Of the Senate Comm. on Banking, Housing, and Urban Affairs, $96^{\text {th }}$ Cong., 2d Sess. 248, 9 (1980) (statement of Irving M. Pollack, quoting letter from former SEC Chairman Ray Garrett to John Sparkman (Nov. 4, 1974)).
} 
approximately $\$ 4$ billion. (See Figure 7). In the meantime, MMFs only broke the buck in 1994 and 2008, albeit with sponsor support from time to time.

\section{FIGURE 7}

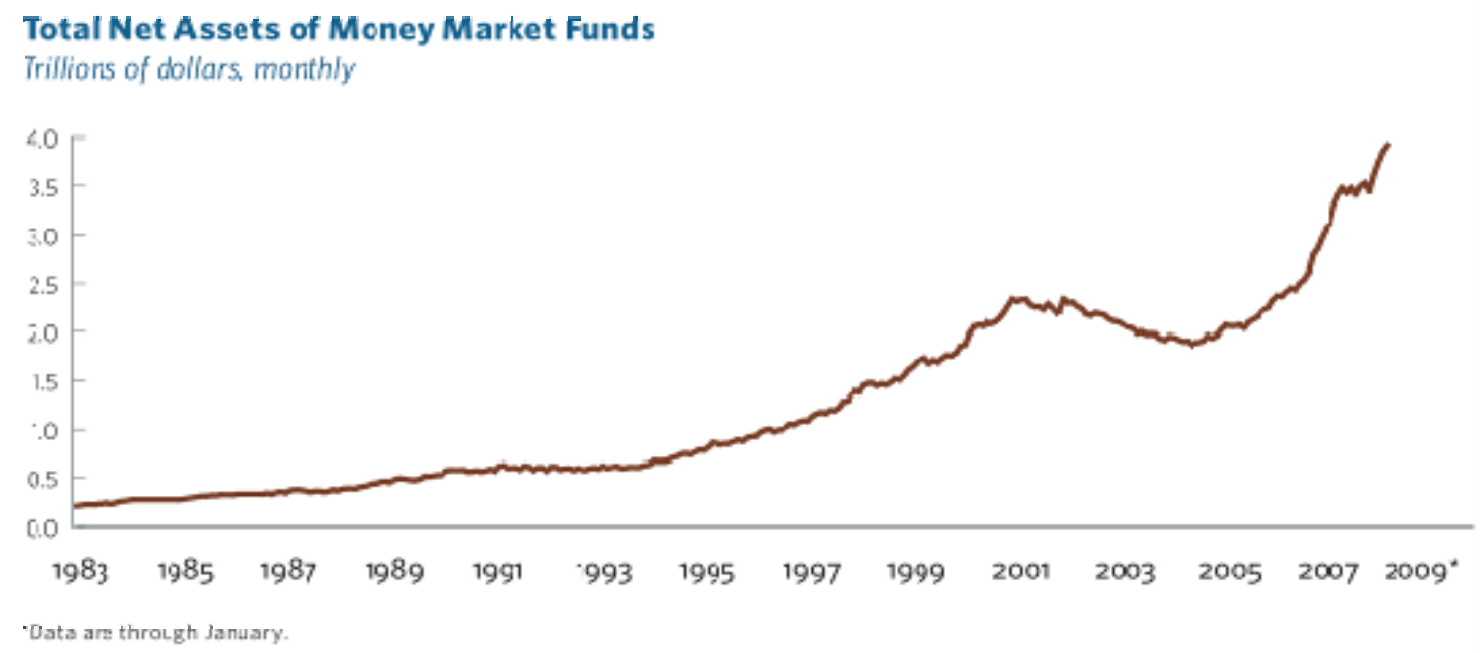

Source: Investment Company Institute

Adopted by the Commission in 1983, Rule 2a-7 requires all money market mutual funds to invest in securities that allow the fund to maintain a stable NAV. ${ }^{110}$ The rule intends to limit money market fund investments "to those investments that have a low level of volatility" and to "provide greater assurance that the money market fund will continue to be able to maintain a stable price per share that fairly reflects the current net asset value per share of the funds." ${ }^{\prime 11}$ To this end, Rule 2a-7 governs the maturity length, credit quality, and diversification of assets that money- market funds can hold, providing risk-limiting conditions in order to reduce the likelihood that a money market fund will break the buck. These risk-limiting provisions all aim to minimize the deviation between a MMF's

\footnotetext{
${ }^{110}$ Investment Company Act Release No. 13, 380 [1982-1983 Transfer Binder] Fed. Sec. L. Rep. (CHH) ๆ 83,400 (July 11, 1983).

${ }^{111} I d$. at 86,050 .
} 
stabilized NAV and the actual market value of its portfolio by limiting the fund's exposure to credit risk and interest rate risk.

The SEC adopted amendments to Rule 2a-7 in 1991 requiring most MMFs to maintain a dollar-weighted average portfolio maturity of not more than 90 days. ${ }^{112}$ Additionally, all assets held by MMFs using an amortized cost basis must have a remaining maturity of 13 months (397 days) or less. ${ }^{113}$ Many commentators have suggested that the 1991 amendments, which further restricted the ability of MMFs to buy high-yield financial instruments, were excessive and anticompetitive. In a 2000 speech at the University of Iowa Law School, former SEC Commissioner Phillip R. Lochner, Jr. expressed his regret for having voted for the 1991 amendments:

From another viewpoint...this decision to impose economic regulation was a failure. By lowering the interest rates that some money market mutual funds were able to earn, and hence pass through to their customers, the SEC denied money market fund customers the higher returns they otherwise would have received. By denying less established issuers the opportunity to sell their commercial paper to money market mutual funds, the Commission raised the costs of capital for those companies.

By reducing the ability of money market mutual funds to compete with banks, the SEC helped protect banks, many of which were widely thought at the time to be inefficient and sleepy, from competition by money market mutual funds. ${ }^{114}$

\footnotetext{
11217 C.F.R. § 270.2a-7(c)(2)(i))(c)(2)(iii) (1994); Revisions to Rules Regulating Money Market Funds, Investment Company Act Release No. 18,005 [1990-1991 Transfer Binder] FED SEC. L. REP. (CCH) ๆ 84,710, at 81,326 (Feb. 20, 1991).

11317 C.F.R. § 270.2a-7(c)(2)(i).

${ }^{114}$ Philip R. Lochner, Jr., Economic Regulation and Democratic Government, 25 J. CORP. L. 831, 832-833 (2000).
} 
Perhaps the most significant provision of Rule 2a-7 is the rule permitting MMFs to use the amortized cost method of valuation and penny-rounding method of pricing. The basic premise underlying MMFs' use of the amortized cost method of valuation is that high-quality, short-term debt securities held until maturity will eventually return to the amortized cost value, and would not ordinarily be expected to fluctuate significantly in value. Therefore, the rule permits money market funds to value portfolio securities at their amortized cost so long as the deviation between the amortized cost and current market value remains minimal and results in the computation of a share price that represents fairly the current NAV per share of the fund. The decision to use amortized cost pricing rests with the MMF board, and cannot be delegated to the MMF adviser. The role of the fund board in serving the interests of the shareholders is another distinguishing feature as compared to banks. Likewise, both the fund's board and the fund's advisor owe a fiduciary duty to the fund's shareholders, which requires that they act in the best interests of fund shareholders. These same protections are not afforded a bank depositor.

The premise of MMF regulation is that the term "money market” mutual fund, as distinct from other kinds of mutual funds, conveys a certain meaning for investors. Specifically, investors, it is generally understood, “expect money market funds to operate conservatively and maintain a $\$ 1.00$ per share net asset value.” As such the long-held view of the SEC is that mutual funds "should call themselves money market" only if they meet criteria consistent with those expectations. ${ }^{115}$

With the regulatory goal of making sure that the term "money market mutual fund" retains its meaning for investors, the SEC in 2010 imposed a variety of additional regulatory requirements on MMFs. The SEC recently passed amendments to these 
regulatory requirements, which will be phased in during 2010 and 2011. The SEC regulates portfolio quality, diversification, liquidity and maturity requirements on any mutual fund that "hold[s] itself out to investors as a money market fund or equivalent."”16 Under the recently amended rules, funds may only refer to themselves as MMFs if, among other requirements, they (1) invest only in securities that the fund's board of directors determines present minimal credit risks; (2) are rated "in one of the two highest short term rating categories" by two NRSROs from a list of four NRSROs previously designated by the funds' board of directors or are of comparable quality ${ }^{117}$; (3) mature within 397 calendar days of the date they are purchased; and (4) meet certain liquidity and portfolio diversification requirements.

Moreover, MMFs are generally prohibited from investing more than 5\% of their total assets in securities from any one issuer, and MMFs cannot allocate more than $2.5 \%$ of fund assets to nongovernmental securities that are not in the highest rating category of the board-designated rating agencies. Perhaps most critically, MMFs must have "a dollar-weighted average portfolio maturity appropriate to its objective of maintaining a stable net asset value per share" and in no event can a MMF have an average weighted maturity that exceeds 60 days.

MMFs are structured to offer the deposit services of banks without imposing the costs of reserve requirements and federal deposit insurance. ${ }^{118}$ Reserve requirements constitute a significant tax on the operation of depository institutions because they do not

\footnotetext{
${ }^{115}$ CARNELL, MACEY \& MiLLER, supra note 10, at 603

116 17 C.F.R. § 270.2a-7.

${ }^{117}$ The recent Dodd-Frank bill requires the SEC (and all federal agencises) to remove references to credit ratings within one year of passage, so the ratings requirement of Rule 2-a7 will change. See Conference Report to H.R. 4173, Title IX, Section 939A.
} 
generate income. Because of the Glass-Steagall Act's separation of the securities and banking industries, banks cannot invest their assets in as wide a range of financial instruments as can MMFs. ${ }^{119}$

In some respects, however, MMFs are more limited than banks in terms of the assets in which they can invest. For instance, banks invest many of their assets in financial markets that money market funds cannot, such as residential, car, or small business loans as well as bonds with long maturities (e.g., 30 years). In accordance with SEC regulations, MMFs must limit their investments to high credit quality, short-term and liquid instruments.

The regulatory approach for banks and MMFs are notably different. Because the individual investor assumes risk in the purchase of securities, the regulation of MMFs is premised on disclosure. Comprehensive disclosure requirements permit an investor to accurately assess the potential risk of an investment and then make an informed decision. To that end, the SEC requires that each investor receive a prospectus before purchasing shares in a MMF and, under the recent Rule 2a-7 amendments, that monthly disclosure of all holdings of the MMF will be made available to the public.

In contrast, because commercial banks assume risk on monies they invest by insuring deposits, banking regulation is premised on examination. In order to ensure that banks meet their obligations to return principal and a predetermined interest payment to

\footnotetext{
${ }^{118}$ Canova, supra note 26, at 1314; Michael Mussa, Competition, Efficiency, and Fairness in the Financial Service Industry, in Deregulating Financial Services: Public Policy in Flux 121, 142-43 (George G. Kaufman \& Roger C. Kormendi, eds., 1986).

${ }^{119}$ Although the Glass-Steagall Act was partially repealed by the Gramm-Leach-Bliley Act, significant restraints on bank securities activities remain. See Jonathan Macey, The Business of Banking: Before And After Gramm-Leach-Bliley, 25 J. CoRP. L. 691, 710, 718-19 (2000); Milton R. SCHROEDER, FinANCIAL SERVICES REFORM, ANALYSIS, AND GUIDELINES ON THE GRAMM-LEACH-BLILEY ACT OF 1999, 1-2 (1999).
} 
depositors, state and federal regulators regularly examine the financial stability and business practices of banks. ${ }^{120}$

There is another basic but important distinction between mutual funds and banks. Shares in a mutual fund are not debt instruments. The fund does not promise to pay back the investor at any specified value, but rather commits to redeem investments based on the fund's NAV at the time of redemption. Whereas banks set an administered rate, MMFs provide a market return. Interests in a mutual fund are thus a form of demand equity rather than demand debt. This feature means that a run on mutual funds is unlikely (and helps explain why such runs have been quite rare when compared to bank products). Even if a customer hears troubling news about a mutual fund in which he or she has invested, there may be little advantage to redeeming shares immediately because he or she will receive only a pro rata share of NAV. There may be a marginal advantage nonetheless for participating in a run on a mutual fund because of concern that NAV will decrease during a run as a result of emergency liquidation of assets to meet customer demand. However, the highly safe asset base and highly liquid nature of MMFs -- which are even more safe and more liquid under the SEC's recent Rule 2a-7 amendments -- make such liquidations extremely rare occurrences. Furthermore, the new rules give the boards of MMFs the ability to suspend redemptions if necessary.

\footnotetext{
${ }^{120}$ See generally, Kenneth E. Scott, The Dual Banking System: A Model of Competition in Regulation, 30 STAN. L. REV. 1 (1977).
} 


\section{Proposed Reforms to Money Market Mutual Fund Regulation}

The Obama administration has strongly endorsed reform of money market mutual fund regulation. In March 2009, Fed Chairman Bernanke encouraged policymakers to "consider how to increase the resiliency of those funds that are susceptible to runs" by “impos[ing] tighter restrictions on the instruments in which money market mutual funds can invest, potentially requiring shorter maturities and increased liquidity," and “develop[ing] a limited system of insurance for money market mutual funds that seek to maintain a stable net asset value.”121 In October 2010 the President's Working Group on Financial Markets (PWG) responded with a report on ways of further regulating money market funds beyond the regulatory amendments already instituted by the SEC.

The money market fund reforms recently adopted by the SEC included several important changes to 2a-7. To constrain the risk-taking of MMFs, the SEC reduced the maximum weighted average portfolio maturity permitted by the rule to 60 days, and limited the weighted average life maturity of portfolio securities to 120 days. The new regulations also permit MMFs breaking the buck to suspend redemptions promptly so as to avoid causing panic. Finally, the rules place more constraints on repurchase agreements between MMFs and third parties.

The SEC has also sought comment on other possible reforms, "recogniz[ing] that the events of the last two years raise the question of whether further and perhaps more fundamental changes to the regulatory structure governing money market funds may be warranted.”122 During the January 27, 2010 Open Meeting, Chairman Schapiro mentioned

\footnotetext{
${ }^{121}$ Bernanke, supra note 90.

122 SEC Proposal, supra note 38 at 101.
} 
five possible reforms - floating NAV, more frequent disclosure of mark-to-market NAV, redemptions in-kind, a private liquidity facility and a two-tiered system of MMFs. Each of these alternatives was analyzed by the PWG in its October 2010 report. The most controversial of them is the proposal to require money market mutual funds to have a "floating" NAV or a NAV that moves daily in line with the value of the fund's underlying investments, rather than the stable $\$ 1.00 \mathrm{NAV}$ prevalent today.

Along with the reforms suggested by Chairman Shapiro, several further reform options were assessed by the PWG. ${ }^{123}$ First, the PWG considered creating private emergency liquidity facilities for MMFs, which would buttress MMFs' ability to withstand capital outflows. Second, the PWG considered requiring that MMFs distribute large redemptions in kind rather than in cash so as to limit liquidity costs to shareholders. Third, the PWG considered some form of government insurance on MMFs to limit the risk of runs on MMFs. Fourth, the PWG considered different ways of creating a two-tier system of MMFs with different provisions for stable NAV MMFs, as suggested by Chairman Shapiro. Fifth, the PWG considered regulating stable NAV MMFs as special purpose banks. Finally, the PWG contemplated enhanced constraints on MMF substitutes that are currently unregulated.

Both current regulation and many of the PWG's future regulatory proposals, particularly the proposal to float the NAV, are premised on the empirically verifiable assumption that people think MMF accounts are either (1) protected by the government; or (2) completely safe for some other reason such as guarantees by the fund families. Survey research by private firms should be done to verify this claim. If these assumptions are false,

${ }^{123}$ The PWG's consideration of further reforms begins on page 18 of its report. 
the solution is to improve investor education, not to abandon the very structure of the MMF industry.

Regulators should therefore aim to accomplish three goals before instituting these reforms: (1) compile empirical research on what money market mutual fund investors think they are risking when they invest in money market mutual funds; (2) further investor education about MMFs to reduce whatever low levels of misinformation are out there; and (3) ensure that the rules we have for MMFs are effective in reducing the susceptibility of funds to breaking the buck.

There has been very little empirical research on the customer's perception as to whether or not money market mutual funds are insured. The most frequently cited evidence of customer confusion stems from an SEC survey released in November $1993 .^{124}$ The study showed that a large percentage of the public believes that all mutual funds are FDIC-insured, including mutual funds sold by traditional mutual fund companies. ${ }^{125}$ Of the 1,000 households surveyed, $47 \%$ owned fund shares, $28 \%$ erroneously believed that mutual funds sold by banks are federally insured, and 49\% believed that money market mutual funds sold by banks are federally insured. ${ }^{126}$ Most surprisingly, 36\% of those surveyed believed that mutual funds bought by a stockbroker are federally insured. ${ }^{127}$

Another survey, conducted by the North American Securities Administrators Association and the American Association of Retired Persons, polled 1,000 adults in

\footnotetext{
${ }^{124}$ See Press Release, Sec. \& Exch. Comm’n, “Chairman Levin Announces Results of SEC’s Mutual Fund Survey,” SEC Press Release 93-55 (Nov. 10, 1993) (Survey prepared by the SEC’s Office of Economic Analysis).

${ }^{125}$ Id.; Jane E. Willis, Banks and Mutual Funds: A Functional Approach To Reform, 1995 Colum. Bus. L. REV. 221 (1995), 252-53; John Waggoner, Bank Mutual Funds Confuse, USA TodAY, Nov. 11, 1993, at 1B. ${ }^{126}$ Willis, supra note 125, at 248; Susan Feyder. Public's Confusion over Mutual Funds Causes Concern, STAR TRIB., Nov. 28, 1993, at 4D ("The biggest risk perhaps is having some little old lady on a fixed income taking her savings and buying aggressive growth funds.”).

${ }^{127}$ Sec. \& Exch. Comm’n,, supra note 124.
} 
October 1993 who said they regularly used a commercial bank. ${ }^{128}$ Of those who had purchased mutual funds from a depository institution, 85\% remembered being given a disclosure document. Nevertheless, $52 \%$ of this group still thought their mutual funds were FDIC-insured. ${ }^{129}$

Since these studies, however, MMFs have substantially increased in size and popularity, and it is reasonable to assume that the general non-investing public has become more educated about mutual funds and that customer confusion has lessened significantly. Furthermore, in the seventeen years since this study, the demographics of investors in MMFs have changed substantially. Whereas retail investors held the majority of MMF assets in 1993, in recent years the balance has shifted to institutional investors, who are more sophisticated and generally demand greater access to market information. At present, \$2.5 trillion in MMF assets (65\%) are held in institutional-share classes, almost twice as much as the $\$ 1.4$ trillion (35\%) held in retail-share classes. (See Figure 2). Institutional investors now hold roughly 7 million shareholder accounts in MMFs, with a median minimum initial investment of $\$ 1$ million. This can be compared with 31 million retail investor accounts, with a median minimum investment of $\$ 1,000$. (See Figure 3).

Some commentators have argued that investors generally believe that money market mutual funds are equivalent to holding cash in a deposit account. ${ }^{130}$ Admittedly, there are both superficial and substantive similarities between MMFs and MMDAs, which result from the original development of MMFs as a substitute for checking accounts and the subsequent development of MMDAs as a reactive effort by depository institutions to

${ }^{128}$ See Most Consumers Unaware, Banking Daily (BNA), Jan. 14, 1994.
${ }^{129}$ Id. 
compete with MMFs. However, investors in MMFs are explicitly warned that investments in money market mutual funds are not equivalent to holding cash in a deposit account, and that they are not insured by the federal government. Money market mutual fund sponsors are required to disclose to their customers that agencies of the United States government neither insure nor guarantee investments in the fund, and that their investments may lose principal. ${ }^{131}$ SEC rules require money market mutual funds to disclose, verbatim:

An investment in the Fund is not insured or guaranteed by the Federal Deposit Insurance Corporation or any other government agent. Although the Fund seeks to preserve the value of your investment at $\$ 1.00$ per share, it is possible to lose money by investing in the Fund. ${ }^{132}$

These disclosures must be prominent not only in prospectuses, but also in any sales literature or advertisements issued by money market mutual funds. This language seems to be sufficiently clear in providing notice to investors that they could lose money in these funds. Of course, it could be amended to make an explicit distinction between bank accounts and MMFs, as some commentators have suggested. ${ }^{133}$ Additionally, the SEC

\footnotetext{
${ }^{130}$ See, e.g., Robert A. Robertson and Bradley W. Paulson, A Methodology For Mutual Fund Derivative Investments, 1 STAN. J.L. BuS. \& FIN. 237 (1994) (positing that media coverage of the mutual fund industry has fostered the impression that MMFs will never lose any principal).

${ }^{131}$ Revisions to Rules Regulating Money Market Funds, Securities Act Release No. 33-6882, Investment Company Act Release No. 18,005, 56 Fed. Reg. 8113-01. 8123 (Feb. 27, 1991).

${ }^{132}$ Investment Company Act Rule 34b-1, 17 C.F.R. § 270.34b-1 (2008); Securities Act Rule 482, 17 C.F.R. § 230.482(b)(4),

${ }^{133}$ See Daniel E. Levin, Breaking The Buck: The End For Money Market Mutual Funds as We Know Them, 28 REV. BANKING \& FIN. L. 747, 771 (2009), recommending the following substitution:
}

An investment in the Money Market Mutual Fund is NOT A BANK ACCOUNT and is NOT INSURED OR GUARANTEED by the Federal Deposit Insurance Company or any other government agency. It is possible to lose money investing in the Fund, including possible loss of some or all of the initial investment. 
could require that fund sponsors send a regular notice to investors reminding them that MMFs are not insured and bear a risk of loss of principal. ${ }^{134}$

The SEC has recently adopted a rule that will require MMFs to provide monthly website disclosure of portfolio holdings, which should allow third-party analysts and commentators to compare MMFs and flag certain aspects of MMF portfolios, both positive and negative. ${ }^{135}$ Third-party analysis will hopefully guide disclosure of the risk characteristics of particular money market funds, and raise a general awareness that investments in MMFs are not necessarily as safe as cash in a bank.

Proponents of a floating NAV argue that by intervening in support of MMFs in September 2008, the federal government gave investors reason to believe that MMFs are, in fact, as safe as cash. If the federal government did indeed confuse investors, a better solution than requiring a floating NAV would be explicit assurance to investors that MMFs are not as safe as cash and that there is no guarantee of a government bailout. The recent financial crisis was an extraordinary circumstance, which witnessed unprecedented federal intervention into financial markets, and investors will certainly understand that there was nothing routine or habitual about the emergency liquidity programs the government put in place during the financial crisis, just as investors recognize that the major government intervention in other financial markets was an extraordinary occurrence.

Even assuming that customers believe that MMFs are insured by the government, regulators can adopt safeguards that would increase customer awareness without risking systemic damage to the economy. However, it is my opinion that the institutional investors who comprise a majority of the investors in MMFs are aware that MMFs are not insured.

\footnotetext{
${ }^{134}$ Id. at 772 .
} 
Furthermore, within the mutual fund industry, MMFs offer investors a wide range of choices. Investors can invest in worldwide funds that are aggressively seeking the highest yields from investments around the world, money funds that invest only in Treasury securities, tax-exempt funds that invest only in tax-free securities, or general purpose funds that invest in CDs, commercial paper, repo transctions or any variety of short-term investments. Generally, MMFs with the least credit risk are the ones invested in securities backed by the full faith and credit of the U.S. government. As with all mutual funds, the risk in MMF investing depends on the quality of the investments that make up the portfolio of any particular MMF. Investors are therefore already in a position to choose a MMF with a yield and risk appropriate to their needs.

Investors and fund managers have argued persuasively against the adoption of a floating NAV, and for good reason. The proposal to no longer permit money market mutual funds to quote a stable NAV of $\$ 1.00$ would, by definition, eliminate the existence of mutual funds that can quote a stable asset value. This would result in a massive inflow of money to banks, which would in turn increase systemic risk, reduce the current level of diversification with respect to how assets are held, and disrupt very long-settled patterns of corporate finance, particularly in the markets for commercial paper and repos.

A stable \$1.00 NAV provides convenience and simplicity to investors and managers alike, boosting MMFs' efficiency with regard to tax, accounting, and recordkeeping. Unlike other mutual funds, MMFs are used primarily as a cash management tool, which means that large transactions flow through them every day. Without a stable NAV, many

\footnotetext{
${ }^{135}$ See Inv. Co. Inst., Report of the Money Market Working Group $92-93$ (March 17, 2009), available at http://www.ici.org/pdf/ppr_09_mmwg.pdf.
} 
investors will bolt for other cash management entities offering a stable NAV in order to minimize tax, accounting, and recordkeeping burdens.

At the Investment Company Institute's Mutual Fund and Investment Management Conference in Phoenix in March 2010, Paul Schott Stevens, the organization's president and chief executive officer, criticized the SEC's proposal for a floating NAV. Stevens emphasized the ICI’s strong opposition to eliminating a steady net asset value of \$1 per share, a fundamental feature of money markets. "Make no mistake: forcing these funds to 'float' their NAV will destroy money market funds as we know them," Stevens said. "It will penalize individual investors and exact a high price in the American economy. But it will not—repeat, not—reduce risks to the financial system. By any measure, it is a bad idea." 136

Stevens noted that mutual funds that float their NAV are not immune to redemption pressure, noting that floating-value funds "lost half their assets in the course of 2008. Clearly, the experience of these other funds demonstrates that a fluctuating per-share value would not eliminate the possibility of wholesale redemptions from money market funds during a future crisis." ${ }^{\text {137 }}$

Stevens expressed his conviction that a floating NAV would cause both institutional investors and small investors to leave MMFs:

As one institutional investor has told us, 'If a money market fund is not dollar-in, dollar-out, you won't have my dollar.' Indeed, many institutions are required by law or by investment policy to keep cash in stable-value

\footnotetext{
${ }^{136}$ Paul Schott Stevens, President and CEO, President's Address, Investment Company Institute, Weathering the Worst: Making Money Market Funds Even Stronger, http://www.ici.org/policy/current_issues/10_mfim_conf_pss_spch. ${ }^{137} I d$.
} 
accounts...[I]nstitutions that want or require stable value would probably turn to the true "shadow banking system" private pools, here and overseas, that promise to maintain a fixed price. These alternatives would neither be registered with the SEC nor subject to regulation under the Investment Company Act 1940, including Rule 2a-7. They would not assure investors the same protections that money market funds do with respect to credit quality, maturity, liquidity, and other aspects of portfolio management. Investors will be more likely - not less - to withdraw their assets from such funds in a future crisis. In short, forcing money market funds to float their values would kill these funds as we know them-without reducing systemic risk. In fact, it seems highly likely that the world would be a riskier place for investors, for issuers, and for the markets. ${ }^{138}$

The PWG has now joined these critics of the floating NAV proposal. Though the PWG acknowledged three ways in which the switch to a floating NAV might help reduce the systemic risk posed by MMFs to some extent, ${ }^{139}$ it ultimately concluded that a floating NAV could be expected to disrupt the everyday functioning of the \$3 trillion MMF marketplace. In particular, the PWG hypothesized that the floating NAV reform would result in lower investor demand, which would reduce the capacity of MMFs to provide short-term credit to businesses, financial institutions, state and local governments, and others. ${ }^{140}$ Additionally, the PWG anticipated that investors would seek stable NAV investment alternatives - like offshore MMFs, enhanced cash funds, and other vehicles that are not subject to the ICA’s restrictions on MMFs - alternatives that may pose more of a systemic risk than MMFs because they are less regulated or entirely unregulated. Finally, the PWG considered other side effects that might follow from the transition from stable to

\footnotetext{
${ }^{138} \mathrm{Id}$.

139 The three ways in which the PWG concluded that a floating NAV might reduce systemic risk are: 1 ) by correcting investors' perception that MMF shares are risk-free; 2) by reducing investors incentives to redeem shares quickly; and 3) by making the rare share price decline of MMFs less dramatic. PWG Report at 19-20. ${ }^{140}$ PWG Report, at 21.
} 
floating NAVs. In particular, a floating NAV could undermine risk management practices as MMFs would no longer need the discipline required to maintain a stable $\$ 1$ share price.

The PWG is correct in predicting that a floating NAV would lead investors to switch out of MMFs. MMFs arose outside of the banking structure in order to provide a better match between the maturity of the assets and the liabilities than bank checking accounts, and to take advantage of Rule 2a-7 regulation. Permitting MMFs to use the amortized cost pricing valuation method pursuant to Rule 2a-7 further enabled them to compete with banks. If money market mutual funds are required to price their assets like a regular mutual fund, they will completely lose their competitive advantage. Eliminating this characteristic strips MMFs of what made them a successful enterprise, causing them to go from being different to being disadvantaged. In summation, requiring money market mutual funds to float their NAV will effectively destroy them entirely.

\section{$\underline{\text { VII. Conclusion }}$}

A deep and well-functioning money market is important to the well being of the macro-economy. The ICI estimates that the size of the money market, including the outstanding values of short-term, instruments such as commercial paper, large CDs, Treasury and agency securities, and repurchase agreements, totals roughly $\$ 12$ trillion. ${ }^{141}$

Requiring MMFs to float their NAVs and so break the buck, or subjecting MMFs to a bank-like regulatory structure would disrupt not only the commercial paper and repo markets, as discussed in Part IV, but also other parts of the short-term money market and increase systemic risk. MMFs hold approximately 23 percent of all repurchase agreements, 
65 percent of state and local government short-term debt, 24 percent of short-term Treasury securities, and 44 percent of short-term agency securities, including securities issued by Fannie Mae, Freddie Mac, and the Federal Home Loan Banks. MMFs are also central players in broader capital markets, holding approximately 22 percent of all state and local government debt, approximately nine percent of all U.S. Treasury securities and 15 percent of all agency securities. ${ }^{142}$

As the SEC mentioned in the proposed rule, "the health of money market funds is important not only to their investors, but also to a large number of businesses and state and local governments that finance current operations through the issuance of short-term debt." ${ }^{143}$ State and local governments rely on tax-exempt MMFs to fund essential public projects such as roads, bridges, airports, hospitals, and low-income housing. According to the ICI, as of December 2008 tax-exempt MMFs had \$491 billion of short-term state and municipal debt under management. ${ }^{144}$

Although risk-limiting reforms are important to ensure the continued safety and security of MMFs, major revisions such as the floating NAV requirement or bank-like regulation would destabilize an industry that has been remarkably stable. In the 39-year history of MMFs, fund managers have "broken the buck” on extraordinarily few occasions.

In conclusion, the strength and singularity of money market mutual funds requires an amortized value calculation for determining net asset value. Destabilizing the NAV would also destabilize the mutual fund industry, the commercial paper market and the repo market, while placing broader capital markets in substantial and unnecessary danger.

\footnotetext{
${ }^{141}$ Inv. Co. Inst., supra note 135 , at 15.

${ }^{142}$ SEC Proposal, supra note 38, at 9.

${ }^{143} \mathrm{Id}$.

${ }^{144}$ Inv. Co. Inst., supra note 6, at 113, tbl.4.
} 